\title{
Striding towards Sustainability: A Framework to Overcome Challenges and Explore Opportunities through Industry 4.0
}

\author{
José Salvador da Motta Reis ${ }^{1, *(\mathbb{D}}$, Maximilian Espuny ${ }^{1}{ }^{\circledR}$, Thaís Vieira Nunhes ${ }^{1}(\mathbb{D}$, \\ Nilo Antonio de Souza Sampaio ${ }^{2}$, Raine Isaksson ${ }^{3}{ }^{-1}$, Fernando Celso de Campos ${ }^{4}$ \\ and Otávio José de Oliveira ${ }^{1} \mathbb{B}$
}

1 Faculty of Engineering (FEG), Sao Paulo State University—UNESP, São Paulo 01049-010, Brazil; maximilian.espuny@unesp.br (M.E.); thais_nunhes@hotmail.com (T.V.N.); otaviodeoliveira@uol.com.br (O.J.d.O.)

2 Faculty of Technology (FAT), Rio de Janeiro State University-UERJ, Resende 27537-000, Brazil; nilo.samp@terra.com

3 Department of Civil and Industrial Engineering, Uppsala University, 75236 Uppsala, Sweden; raine.isaksson@angstrom.uu.se

4 Faculdade de Engenharia Arquitetura e Urbanismo (FEAU), Universidade Metodista de Piracicaba_UNIMEP, Santa Bárbara d'Oeste 13450-000, Brazil; fernccampos@gmail.com

* Correspondence: jmottareis@gmail.com

check for updates

Citation: Reis, J.S.d.M.; Espuny, M.; Nunhes, T.V.; Sampaio, N.A.d.S.; Isaksson, R.; Campos, F.C.d.; Oliveira, O.J.d. Striding towards Sustainability: A Framework to Overcome Challenges and Explore Opportunities through Industry 4.0. Sustainability 2021, 13, 5232. https:// doi.org/10.3390/su13095232

Academic Editor: Julian Müller

Received: 29 March 2021

Accepted: 30 April 2021

Published: 7 May 2021

Publisher's Note: MDPI stays neutral with regard to jurisdictional claims in published maps and institutional affiliations.

Copyright: (c) 2021 by the authors. Licensee MDPI, Basel, Switzerland. This article is an open access article distributed under the terms and conditions of the Creative Commons Attribution (CC BY) license (https:// creativecommons.org/licenses/by/ $4.0 /)$.
Abstract: Sustainability 4.0 (S4.0) enables sustainable development through intelligent technologies to meet economic, environmental and social demands. The main objective of this article is to propose a framework for developing S4.0 in sectors of Triple Helix (TH) (Government, Organizations and Academy). The framework consists of benchmarking of policies and initiatives from the ScienceTechnology Scenario in S4.0 (STS-S4.0) and the author's experience. The STS-4.0 is a snapshot of relevant initiatives from the countries that performed best in science and technology in S4.0. This work uses the methods of bibliometric studies and content analysis of scientific articles from the Scopus database and patents publications from the Orbit database. This research resulted in a total of 19 propositions for developing sustainability through I4.0. Of these, eight are for Government, six for Organizations and five for Academy. The main scientific contribution of this work is to expand and deepen the recent block of knowledge on S4.0. As for the applied contribution, this work contributes to the conscious and sustainable development of humanity through the technological elements of I4.0, contributing to the achievement of the following SDGs proposed by the UN: 9 (Industries, Innovation and Infrastructure), 11 (Sustainable Cities and Communities) and 13 (Climate Action). The main novelty of this article is the creation of paths for Government, Organizations and Academy to interactively lead the development of global sustainability through the smart technologies of I4.0.

Keywords: Sustainability 4.0; Industry 4.0; Sustainable Development Goals; intelligent technologies; Triple Helix

\section{Introduction}

Human activities have caused changes to almost 75\% of the Earth's surface, causing negative consequences to the fauna and flora [1]. Environmental impacts are among the main causes of diseases and deaths in the world, an estimated $25 \%$ of which due to the consumption of inappropriate water, inhalation of polluted air, among others [2]. Preserving the planet requires an economy based on patterns of conscious consumption, that is, patterns that fit nature's regeneration capacity. Sustainable organizations are long-lived, with the maintenance of a greater number of jobs and income, increasing social actions for the community [3]. The balanced development of the pillars of sustainability (environmental, economic and social) allows society to move toward sustainable development [4].

Sustainable development was presented in the Brundtland Report as the ability to meet the current needs of society without compromising the basic living conditions of 
future generations [4,5]. Following this logic, Elkington (1998), proposed the Tripple Bottom Line (TBL) in which organizations must go beyond the results in the economic dimension, also contributing to the environmental and social dimensions [4]. Thus, improving the level of sustainability can be understood as a journey toward sustainable development through a change that upgrades from a level of non-sustainability toward sustainability [6-8]. To better direct global economies toward a state of sustainability, the United Nations proposed, in 2015, the 2030 Agenda, which established 17 Sustainable Development Goals (SDGs) (Figure 1) [9].

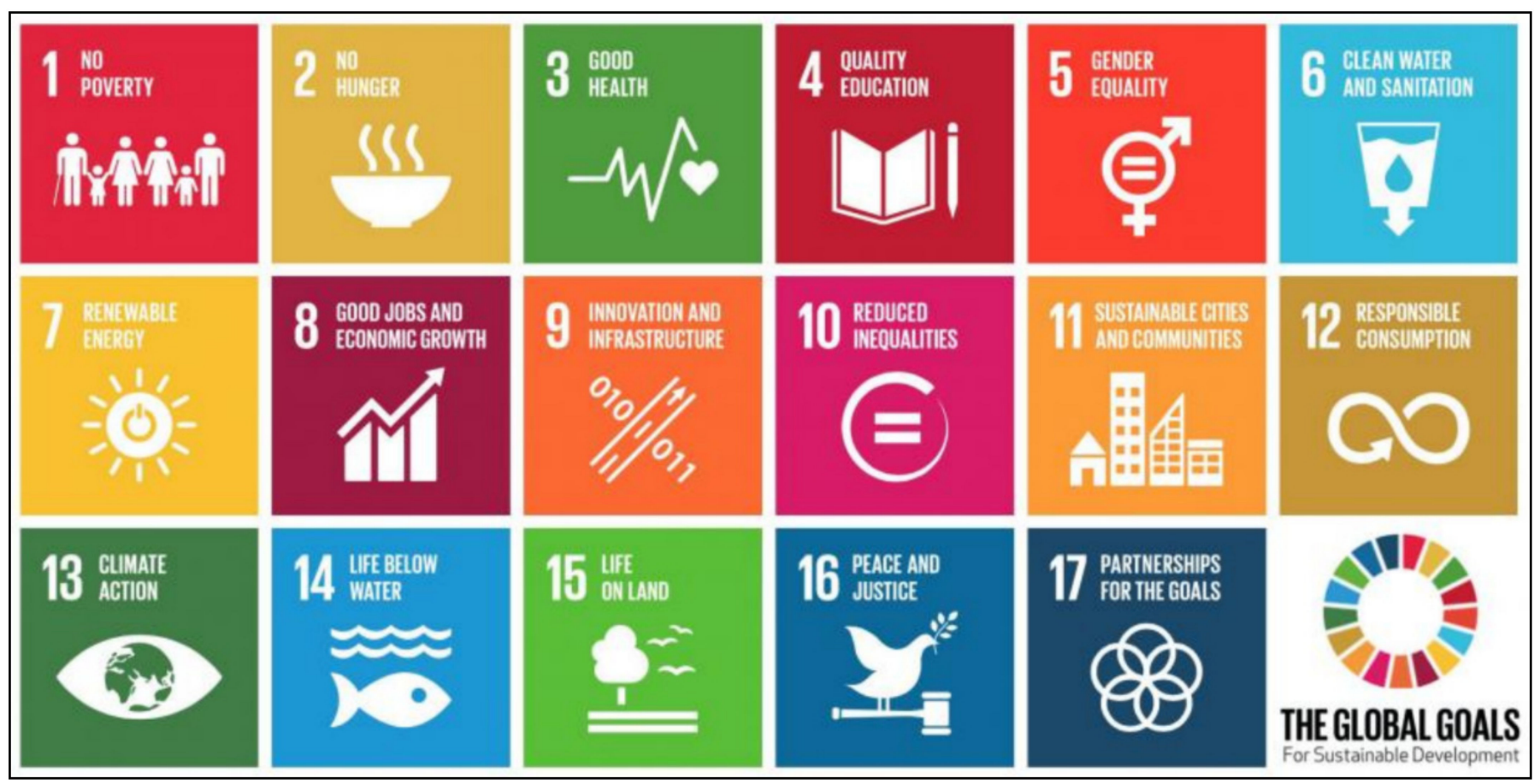

Figure 1. 17 Sustainable Development Goals. Source: [10].

Along the same lines, the Davos Manifesto was presented at the World Economic Forum of 2020. Among the main recommendations of this manifesto are the fair payment of taxes, zero corruption, protection of the environment, valuing employees, ethical conduct and commitment to human and labor rights. The same event discussed the impacts of the Fourth Industrial Revolution (FIR) on sustainable development [11].

FIR involves changing the paradigm from automated processes to intelligent processes, which combine physical and virtual environments in a cyber-physical environment to improve processes by sharing information in real-time between machines, suppliers and customers. It also supports industrial automation processes and fosters business collaboration through advanced planning techniques distributed across different sectors, integrated logistics management and interoperability of information systems [12,13]. Therefore, this transformation is based on intensive use of digital and other types of technologies, which are deeply interdependent. Thus, FIR encompasses technological innovations (automation and information technology) for faster, more flexible and efficient manufacturing and processes, bringing together physical and digital resources [14,15]. There is a set of nine main technologies involved in this digitalization process, which have been called Enabling Technologies of Industry 4.0. They are Cyber-Physical Systems (CPS), Internet of things (IoT), Big Data and Analytics, Autonomous Robots, Augmented Reality (AR), Additive Manufacturing, Cloud Computing, Cybersecurity and Simulation [16,17].

The main technological movement of the FIR started in 2011 as part of the High-Tech Strategy 2020 action plan of the German government which was named Industry 4.0 (I4.0), so I4.0 has become the reference of the FIR $[12,18,19]$. The United States contributed to 
the FIR with the Industrial Internet technological movement, which brings together the industries and technologies necessary to accelerate the growth of the Industrial Internet [20]. The Chinese also collaborated with the development of FIR by implementing the Made-inChina 2025 (MiC2025) strategic plan, created in May 2015 to foster the country's industrial development by 2025 [21].

If an organization wants to do more with sustainability, I4.0 can help achieve this goal. I4.0 can bring various economic, environmental and social benefits for organizations, which in turn reflect in contributions to sustainable development. This can be explained by the fact that I4.0 provides ways to accelerate the rationalization of processes, resulting in less waste in general throughout the processes resulting from the rational reasonable of water, electricity, reduction in $\mathrm{CO}_{2}$ emissions, less material in process and packaging, reduced set-up times, shorter lead times, among others [22-24]. The implementation of enabling technologies for I4.0 provides "intelligence" to production processes and can improve the conditions of sustainability in production by increasing energy efficiency, reducing production costs, promoting greater connectivity, reducing environmental impacts, among others $[19,25-28]$. The alignment of sustainability with I4.0 forms a recent line of knowledge called Sustainability 4.0 (S4.0), which can be understood as a strategy to support achieving a state of sustainability through intelligent technologies to meet a balanced development of economic, environmental and social demands [29-31]. Research on the main initiatives of S4.0 allowed its intensified development from $2015[19,28,32,33]$. In this context, the three sectors of the Triple Helix (TH), Government, Organizations and Academy (Figure 2), can strengthen S4.0 through strategies, legislation, creation and implementation of new intelligent technologies and alignment of industries with sustainable development $[18,34,35]$.

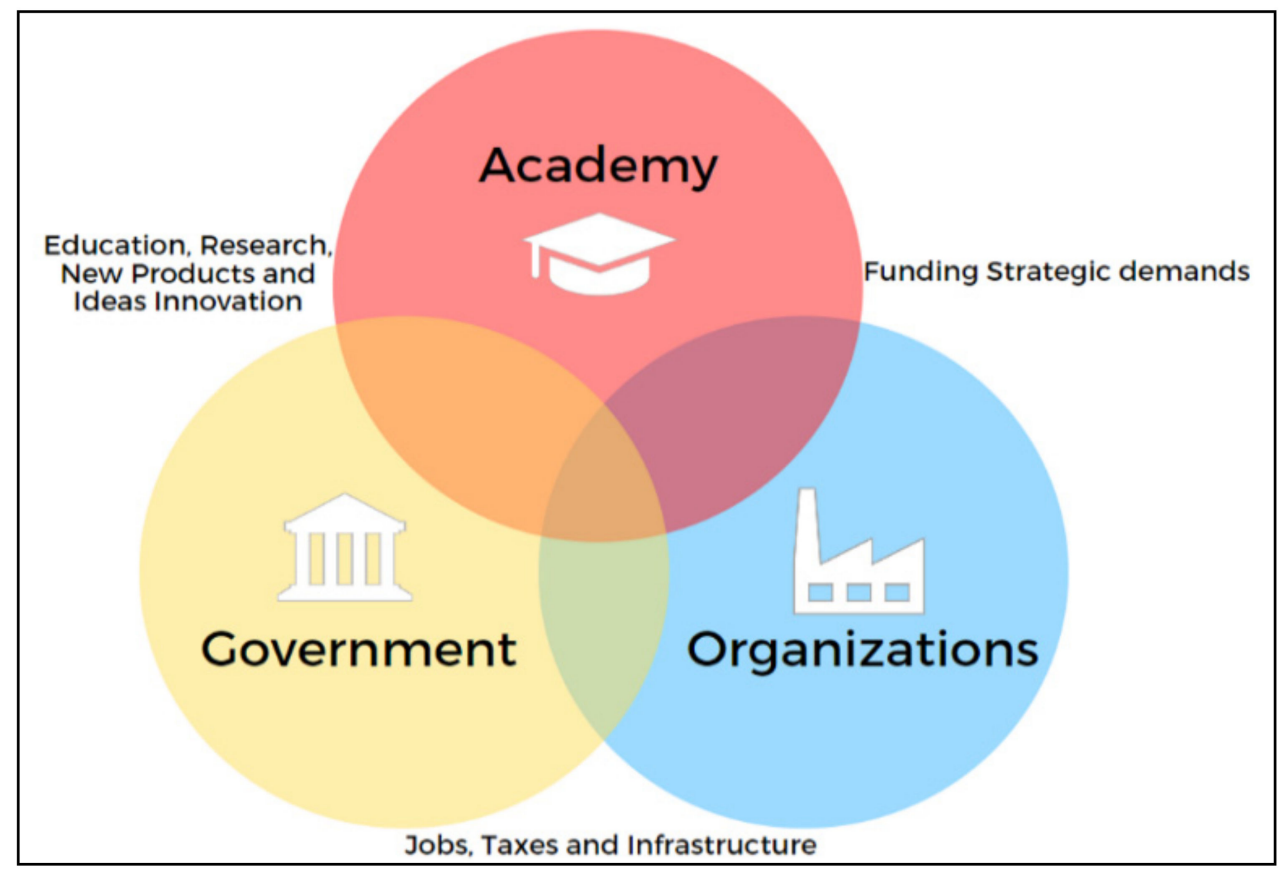

Figure 2. Triple Helix model. Source: Adapted from Ranga \& Etzkowitz (2013) [36].

Some of the main studies on the theme are Jabbour et al. (2018), who identified factors critical to the success of S4.0, such as an integrated approach to sustainable production in I4.0 [25]; by Kamble et al. (2018) and Kiel et al. (2017), who addressed the contributions of I4.0 to corporate sustainability, identifying contributions such as increased competitiveness, reduced environmental impacts, increased human learning, among others [29,37]; by Haseeb et al. (2019) and Müller et al. (2018), who analyzed environmental and social strategies as drivers for the implementation of S4.0, and challenges in organizational environments that hinder the implementation of I4.0 technologies in small and medium-sized 
companies $[33,38]$. In these studies, it is possible to identify challenges and opportunities to develop S4.0 and they are essential to motivate this work. To explore these opportunities and overcome these challenges, this work proposes alternatives to develop S4.0. Thus, this paper aims to fill the following scientific gap: Lin et al. (2017) says it is necessary to propose new strategic initiatives that make I4.0 and sustainability interact [39].

The motivations for conducting this work are threefold. The first is the scarcity of studies that relate the TBL dimensions to I4.0 $[38,40]$. The second is to reconcile the high performance of smart industries without frustrating consumer ecological and social expectations, because products that cause environmental and social impacts lose market [41]. The third is to encourage industrial organizations to manufacture eco-friendly products [42].

This article indicates actions that foster the development of I4.0 technologies to improve environmental performance. At the same time, it encourages that these technologies do not negatively impact the global sustainability network. Therefore, "how is it possible to contribute to sustainability with the help of I4.0?" is the question that guides this research. To answer this question, this paper proposes a framework for developing S4.0 in the Government, Organizations and Academy sectors of TH. The development of the framework is based on benchmarking the policies and initiatives in the Science-Technical Scenario on S4.0 (STS-S4.0) added to the author's expertise, contemplating strategies, technologies and initiatives that can be adopted by the TH sectors. The STS-4.0 is a snapshot of relevant initiatives from the countries that performed best in science and technology in S4.0. This paper has six sections. After this introduction, the method of this research follows (Section 2). Section 3 introduces the STS-S4.0. Section 4 presents the S4.0 development framework and Section 6 brings the conclusions. Finally, the last part is the list of references.

\section{Scientific Method}

The methodological flowchart of activities for developing follow in Figure 3.

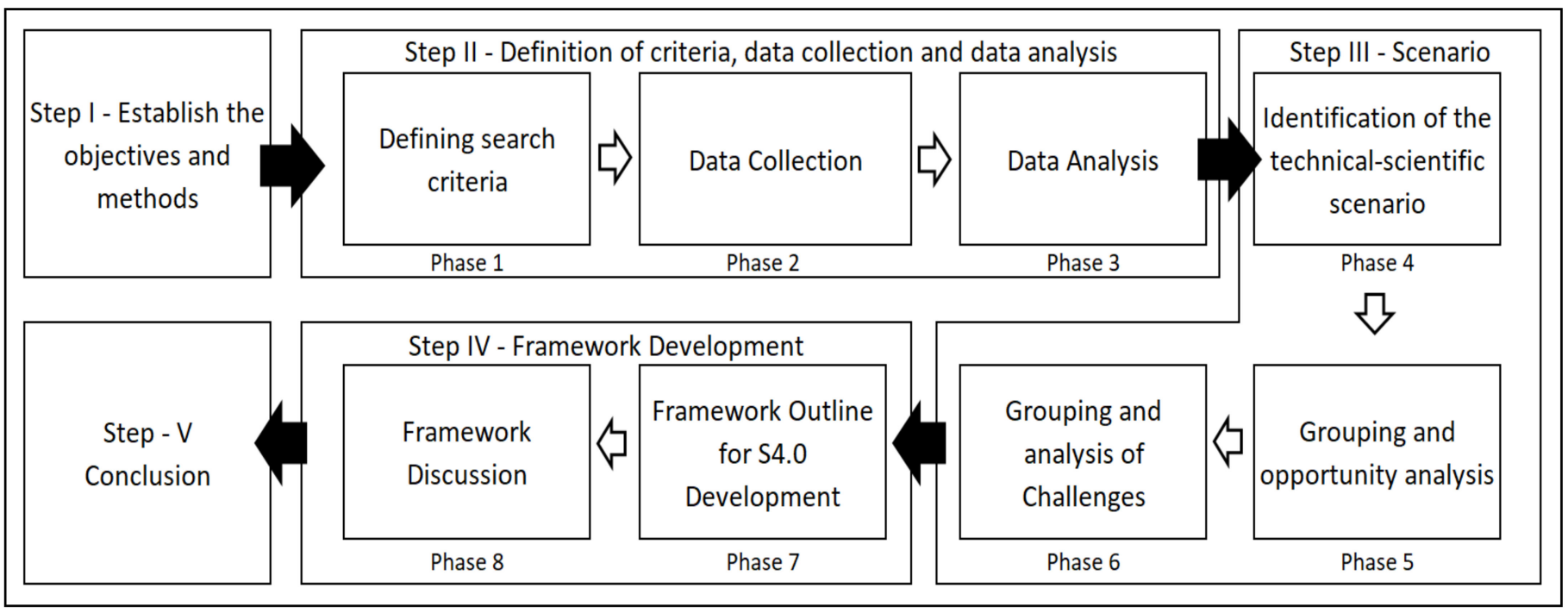

Figure 3. Methodological flowchart. Source: Authors.

The research has five steps: step I-definition of research objectives and method; step II-definition of research criteria, data collection and analysis; step III-STS-S4.0 mapping; step IV-proposition of the framework for S4.0; step V-conclusion and synthesis of contributions. Step I presents the research objectives and the methods for achieving them. This study uses a combined method of bibliometric analysis and content analysis. Bibliometric analysis allows quantitative measurement of technical and scientific advances in a given subject and to identify the characteristics of their development $[43,44]$. Content analysis is a method for interpreting textual data through the systematic process of identifying themes or patterns. This type of analysis allows building knowledge and understanding 
the phenomenon under study [45]. This scientific mapping, added to the content analysis of articles, public documents, patents, among others, allows the interpretation of the subject and the construction of new pathways through the proposal of a framework for developing S4.0.

Step II follows three phases: phase 1-definition of the search criteria; phase 2-data collection; phase 3-data analysis. Phase 1, has the selection criteria and delimitation of data collection. The database for data collection is Scopus and Orbit. The articles are from February 2020 and belong to the Scopus database. The preference for Scopus is because this database includes most of the articles available in the Web of Science (WOS) database. Additionally, Scopus has unique articles that are excluded in WOS. The articles that are in both databases, in all cases, have more citations in Scopus than in WOS. The period from 2015 was chosen because this year saw the beginning of publications involving sustainability and I4.0 topics. As of 2015, there is an increasing interest in both themes together [46-48]. The papers are in the English language, as it influences and impacts the Academy to a greater extent than other languages [43]. The development of the technical scenario is based on patents, as of July 2020 in the Orbit database. This database gathers patents from more than 100 offices around the world, making it possible to analyze the development of S4.0-related technologies. The terms "Sustainability" and "Industry 4.0" form the basis of the terms suggested by the platform as patent selection criteria (Table 1).

Table 1. Keywords of Data Collection. Source: Authors.

\begin{tabular}{ccc}
\hline Clusters & Associated Words SCOPUS & Associated Words ORBIT \\
\hline Sustainability & Sustainability; Sustainable & Sustainability; Sustainable \\
\hline & Industry 4.0; Industrial 4.0; & Smart Machine; Smart Manufacturing; Smart \\
& Industrie 4.0; Manufacturing & Factories; Smart Factory; Cyber-physical \\
Industry 4.0 & 4.0; The Fourth Industrial & Systems; Internet of Things; Internet of \\
& Revolution; 4.0; Smart Factory; & Services; Cloud; Big Data; Machine Learning; \\
& Smart Manufacturing; Smart & Deep Learning; Artificial Intelligence; \\
& Factories & Intelligent Manufacturing \\
\hline
\end{tabular}

Phase 2 follows with information on 94 articles from the Scopus platform and 208 patents from the Orbit platform, according to the search criteria from phase 1 . Phase 3 continues with the analysis of data from phase 2 , ranking the top countries according to the relationship between two criteria: H-Index and the number of patents filed (Figure 4). The H-Index quantifies the impact and relevance of scientific research, being a bibliometric metric that measures the academic productive capacity of countries, universities, authors, among others [49]. Initially, the 10 countries with the highest H-Index and the 10 countries with the highest number of registered patents were ranked (Appendix A). Countries that tied in the number of publications or patents were ranked in the same position. Next, the countries that were present in both columns were identified, using an index composed of the average of the positions between the H-Index Position and Patent Position variables.

In this index, the lower the average value among the variables, the better the positioning of the country, according to the Final Position Index (Figure 4). The first countries have the highest $\mathrm{H}$-Index and hold $80 \%$ of all patents. Considering these criteria, India, the United States of America, China and Germany are selected countries. Step III has three phases (phases 4, 5 and 6), focusing on the development of STS-S4.0: phase 4-STS-S4.0 subject mapping; phase 5-opportunity analysis and clustering; phase 6-challenge analysis and clustering. Phase 4 has the content analysis, systematizing the main innovations and governmental, industrial and academic initiatives of the four countries highlighted in STS-S4.0, from the perspective of the TH model. This systematization allows the creation of a framework that contributes to the development of initiatives that combine actions of public and private authorities [50]. Thus, this paper analyzes official documents, such as reports from national and international bodies, government web pages and countries with the highest number of patents related to S4.0. 


\begin{tabular}{|c|c|c|}
\hline \multicolumn{2}{|c|}{ H-Index Position } \\
№ & Countries & H-Index \\
\hline 1 & Germany & 6 \\
\hline 2 & India & 5 \\
\hline 3 & Brazil & 4 \\
\hline 4 & $\begin{array}{c}\text { United States of } \\
\text { America }\end{array}$ & 4 \\
\hline 5 & France & 3 \\
\hline 6 & China & 3 \\
\hline 7 & United Kingdom & 3 \\
\hline 8 & Malaysia & 2 \\
\hline 9 & Estonia & 2 \\
\hline 10 & Sweden & 2 \\
\hline
\end{tabular}

\begin{tabular}{|c|c|c|}
\hline \multicolumn{3}{|c|}{ Patent Position } \\
№ & Countries & Patents \\
\hline 1 & China & 200 \\
\hline 2 & $\begin{array}{c}\text { United States } \\
\text { of America }\end{array}$ & 134 \\
\hline 3 & India & 39 \\
\hline 4 & Canada & 7 \\
\hline 5 & Australia & 3 \\
\hline 5 & South Korea & 3 \\
\hline 6 & $\begin{array}{c}\text { United } \\
\text { Kingdom }\end{array}$ & 2 \\
\hline 6 & Hong Kong & 2 \\
\hline 7 & Germany & 1 \\
\hline 7 & Brazil & 1 \\
\hline
\end{tabular}

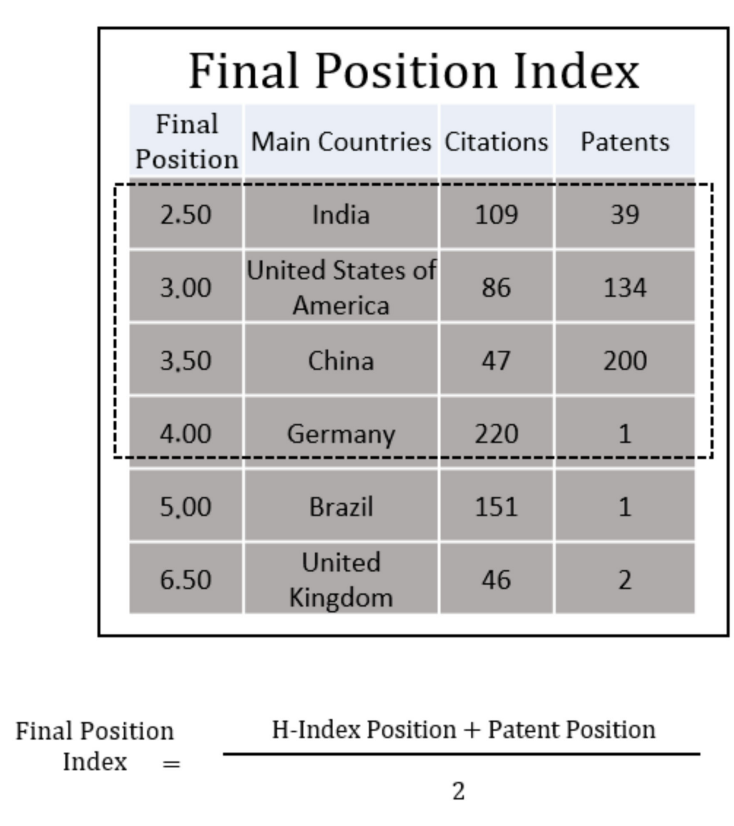

Figure 4. Ranking of countries. Source: Authors.

In phases 5 and 6 the authors identify and group the main opportunities and challenges for S4.0 development (Appendix B). The basis for the groupings is the content analysis of the most citation 30 articles realized in phase 2. Step IV was developed in two phases (Figure 5): phase 7-definition of the sectors of the framework, and phase 8discussion of the framework. Phase 7, mentions the main initiatives, opportunities and challenges for developing STS-S4.0. Phase 8 the authors elaborate the Framework.

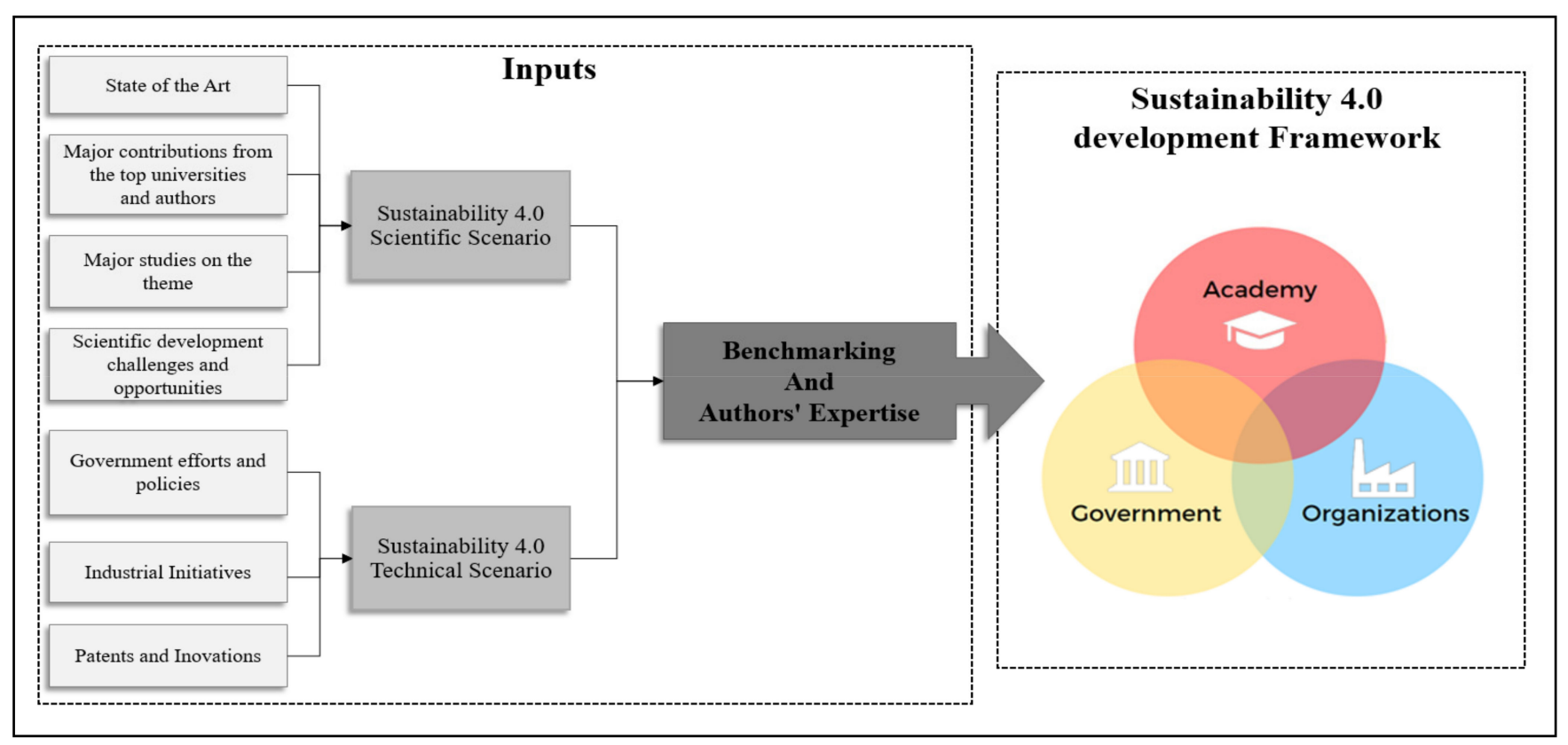

Figure 5. Framework elaboration flowchart. Source: Authors, and Adapted from Ranga \& Etzkowitz (2013) [36].

Step $\mathrm{V}$ presents the fulfillment of the objectives of this work, its main scientific and applied contributions, its limitations and, finally, suggestions for future studies. 


\section{Scientific-Technical Scenario}

This topic presents the current STS-S4.0, with the main countries that stood out in terms of the development of studies and techniques on the topic. Following the flowchart structure of the framework, the analysis of the STS-S4.0 will be detailed for each of the four countries in the ranking: India, United States of America, China and Germany. These countries seek to implement I4.0 technologies to contribute to sustainability, demonstrating that even countries with economic, environmental and/or social problems can have initiatives that leverage S4.0 to improve their current scenario.

\subsection{India}

India is the third country with the highest number of patents registered for S4.0 (39) and the second about to with concerning the H-Index [51,52].

\subsubsection{Government}

The Indian Government, in partnership with industry and civil society, created the Confederation of Indian Industry (CII) for developing national manufacturing. The CII focuses on six key elements: Human Development; Corporate Integrity and Citizenship; Business Simplification; Innovation and Technical Capacity; Sustainability; and Global Integration. The CII has a sustainability development plan that uses I4.0 technologies [46]. The National Policy for Advanced Manufacturing Plan was created to encourage technological advancement in the Indian industry. It encourages the implementation of new I4.0 technologies to improve manufacturing production, making production processes more sustainable through the development of cybersecurity, increased social connectivity and energy efficiency $[31,33,46]$.

\subsubsection{Organizations}

According to the search carried out on the Orbit platform, the organization that most developed patents in the area of S4.0 were Schneider Electric, from India. The Schneider Electric Industries develop digital solutions with a focus on sustainability for the energy sector. They have patents registered in India in the areas of Computer Technology and Thermal Processes and Apparatus, aimed at creating software and intelligent electrical devices $[52,53]$. The Schneider Electric Industries developed the EcoStruxure ${ }^{\mathrm{TM}}$ platform, which integrates the electrical and cybernetics environments of homes, buildings, data centers and industry [54]. This platform works through IoT and sensing connected devices (electrical and electronic). It enables people within an integrated environment to monitor and manage electronic equipment quickly and interactively, with greater energy efficiency, increased security and reduced energy costs [31,54-56].

The startup VST Mobility Solutions (VST) develop software and hardware for use in mobile devices used in supply chains. VST uses IoT and Cloud Computing for end-to-end fleet management in supply chains, collecting vehicle data to be accessed remotely by users, allowing the monitoring and management of an unlimited number of vehicles in real-time $[57,58]$. Implementations such as VST software provide greater energy efficiency in activities and processes, increase driver safety and reduce supply chain costs $[31,38,47]$. VST created the BIN-19 device which, based on I4.0 technologies, allows the deposition of protective masks and their disinfection by ultraviolet light. It also sanitized the hands depositing masks with sanitizing fluid, ensuring the safety of users against exposure to viruses and bacteria [59]. BIN-19 helps reduce people's exposure to viruses in pandemic situations, reduces improper disposal in the environment and prevents the disposal of biohazardous materials in inappropriate locations $[31,60,61]$.

\subsubsection{Academy}

The three universities with the highest H-Index for S4.0 are the National Institute of Industrial Engineering (NIIE), the State Institute of Engineering and Technology (SIET) and the Indian Institute of Technology Delhi (IITD). NIIE research group studies the field 
of I4.0 that focuses on sustainability, identifying trends in sustainable I4.0 and analyzing trends in the implementation of I4.0 technologies to leverage sustainable production [37,62]. SIET has developed studies that identify critical factors for the implementation of I4.0 technologies aimed at sustainability in organizations. The results showed that managerial and economic factors are the most critical for the implementation of sustainability measures, while environmental factors are important, and can already be better calculated for sustainability [63]. SIET researchers have proposed a theoretical framework to achieve sustainability in the supply chain through I4.0 technologies $[64,65]$. The author from India with the highest H-Index is Dr. Sunil Luthra, who is affiliated with SIET. He works in partnership with authors who hold the second and third largest $\mathrm{H}$-index on the topic, Dr. Anil Kumar, who is affiliated with BML Munjal University, and Dr. Gunjan Yadav, who is affiliated with SV National Institute of Technology, respectively. They contribute to research that supports organizational managers to incorporate environmental protection, increasing the safety of processes and the well-being of employees involved in the supply chain, identifying and analyzing the challenges for sustainability in emerging economies when implementing I4.0 technologies [65].

IITD has initiatives aimed at analyzing the climate change, reducing the impacts on the planet, investigating new energy sources and implement I4.0 technologies to improve sustainability standards in the manufacturing and supply chain $[37,42,66]$.

\subsection{United States of America}

The United States of America are the second country with the highest number of patents registered for S4.0 (134) and the third in H-Index (4) [51,52].

\subsubsection{Government}

The United States government created the United States Environmental Protection Agency (EPA) to develop policies to preserve life and the environment. Among the main actions carried out by EPA are the first assessments of major ecosystems, analysis of the risks posed by tobacco smoke, the discovery of the harmful effects of lead in gasoline, among other actions $[67,68]$. The EPA website holds lists of government initiatives such as Chicago's Array of Things (AoT), an urban sensing project. The AoT measures factors such as climatic conditions, air quality, noise pollution and provides tools for improving urban planning that impacts civilian housing. Through policies to preserve life and the environment, the United States was able to reduce greenhouse gas emissions per capita by 17\% between 2006 and $2016[69,70]$.

\subsubsection{Organizations}

According to searches carried out on the Orbit platform, the organizations that most developed patents in the area of S4.0 were International Business Machines (IBM), Xerox and SunTracker Technologies (STT) (Figure 6). 


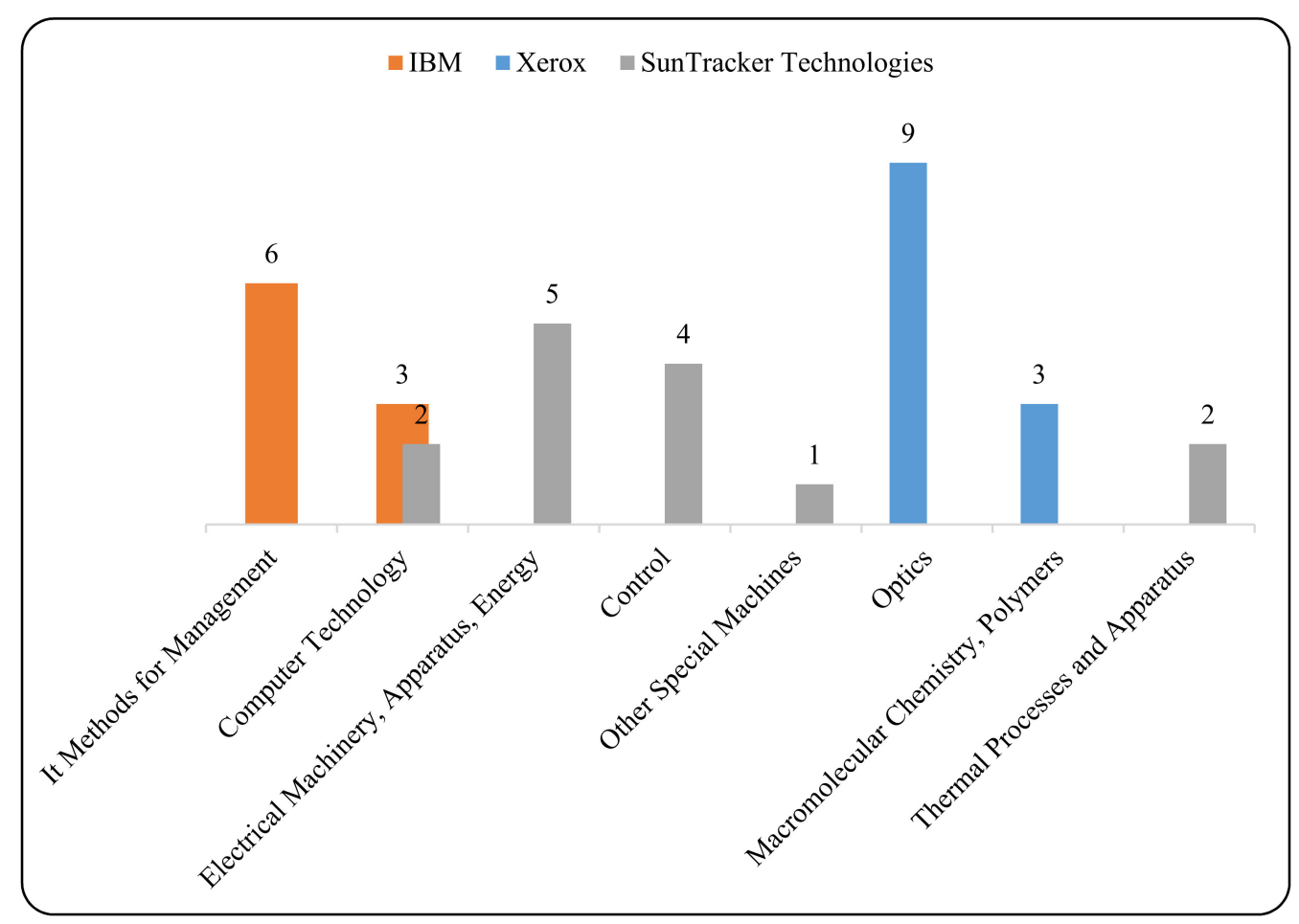

Figure 6. Patent groups from American organizations. Source: Orbit (2020) [52].

IBM, a product and service developer in the area of information technology, was the American organization that registered most research patents. These patents belong to the areas of IT Methods for Management and Computer Technology, developed to reduce waste, increase efficiency in the use of energy and water and reduce $\mathrm{CO}_{2}$ emissions, promoting sustainable ecosystems and healthy financial management [52,71]. IBM has an "Energy and environment" line of research, with the objective of developing intelligent systems that optimize water and energy resources, controlling power plant energy flows. These intelligent systems help to contain abrupt power interruptions, restoring power more quickly than average. IBM also works to create transport systems that optimize the flow of motor vehicle traffic and reduce $\mathrm{CO}_{2}$ emissions. The company also develops systems that enable automated predictive actions in the management of water treatment, proposing corrective actions [72].

Xerox operates in the information technology and computing component sectors, developing scanning equipment and printer components with patents registered in the areas of Optics and Macromolecular Chemistry, Polymers [52,73]. Xerox developed the DocuShare ${ }^{\circledR}$ document content management platform, which allows users to digitize papers in a central management system, where documents are measured, managed and stored securely for users to access. DocuShare ${ }^{\circledR}$ makes it possible to reduce paper use, contributing to the reduction or even extinction of physical files [74]. This platform digitized 500,000 documents from the century-old furniture maker Fairfield Chair. Digitizing documents significantly reduced reliance on physical files. With this action, this company reduced its space use by $40 \%$, reducing its carbon footprint and, consequently, improving its sustainability results $[31,75,76]$.

STT has registered patents in the areas of Computer Technology; Electrical Machinery, Apparatus, Energy; Control; Other Special Machines; and Thermal Processes and Apparatus. Patents are applied to the development of greenhouse lighting designing software [52,77]. One software developed by STT was Cerise365 + GreenHouseDesigner, using sensing and Big Data. This software allows to pre-design the need for artificial lighting that a greenhouse will need on site. The use of this software makes it possible to enhance agricultural yield, increasing food production and impacting sustainability 
in environmental, economic and social pillars, helping to mitigate the global problem of hunger [78-81].

\subsubsection{Academy}

The three universities with the highest H-Index in scientific production on S4.0 are the California State University Bakersfield (CSUB), the Cognitive Labor Institute (CLI) and the Institute of Smart Big Data Analytics (ISBDA). CSUB has a line of research and projects in the area of sustainability that is divided into nine sub-areas: administration, construction, education, energy, food, transport, waste management and water. In each of these subareas there is the implementation of I4.0 technologies, such as the use of Big Data and Virtual Reality (VR) in the area of education. This line of research improves the three pillars of sustainability [82,83]. At CSUB, Dr. Angappa Gunasekaran has the highest H-Index for research on the topic. This author identified the synergies and dissonances between I4.0 and Lean Manufacturing in the context of Sustainability and developed a study that identifies sustainable applications of I4.0 technologies in manufacturing processes $[37,84]$.

CLI carried out research in the area of data analysis, intelligent technologies and IoT to improve data processing and add value to the production process. These technologies improve operational, economic and environmental performance, contributing to raise the level of sustainability of industrial processes $[31,85,86]$. Dr. Caryl Tuffnell works at the CLI and is the second author with the highest H-Index on the topic of S4.0. This author investigates the impacts of excessive data traffic on business costs, looking for viable alternatives for corporate economic sustainability [85,87].

The ISBDA belongs to the American Association for Economic Research and does research aimed at intelligent and sustainable manufacturing, using I4.0 technologies to make supply networks economically and environmentally sustainable. [88-90]. The third author with the highest H-index within the S4.0 topic, Dr. Joseph Sarkis, is affiliated with Worcester Polytechnic. In his research, he proposes the adoption of technologies such as nanotechnology, mobile technology and drones to improve the impact of the environmental and economic sustainability of automotive, electronic, food and textile industries, which are directly impacted by I4.0 technologies [22,91].

\subsection{China}

China is the country with the highest number of patents registered for S4.0 (134) and the fourth in H-Index (3) [51,52].

\subsubsection{Government}

To make the country more sustainable, China developed a plan to address agricultural development, solid waste management, factory pollution, increased energy efficiency and the implementation of enabling technologies for smart environments to improve manufacturing standards [92]. The multilateral financing and development institution Asian Development Bank (ADB) supports the Chinese government plan prioritizing the topics of climate change, environmental degradation and economic growth [93]. The MiC2025 program was also instituted for the implementation of enabling technologies of I4.0 in the industry. The MiC2025 made it possible to improve industrial performance, strengthen the economy, reduce environmental degradation and favor social inclusion. Its focus is on low carbon industries, information technology, aerospace and nuclear research. Therefore, MIC20205 is a program that drives industrial development and sustainable growth in China [94-96].

\subsubsection{Organizations}

According to searches carried out on the Orbit database, the organizations that most developed patents on S4.0 were Southeast University (SEU), China Datang (CD) and Zhejiang Haikang Technology (ZHT) (Figure 7). 


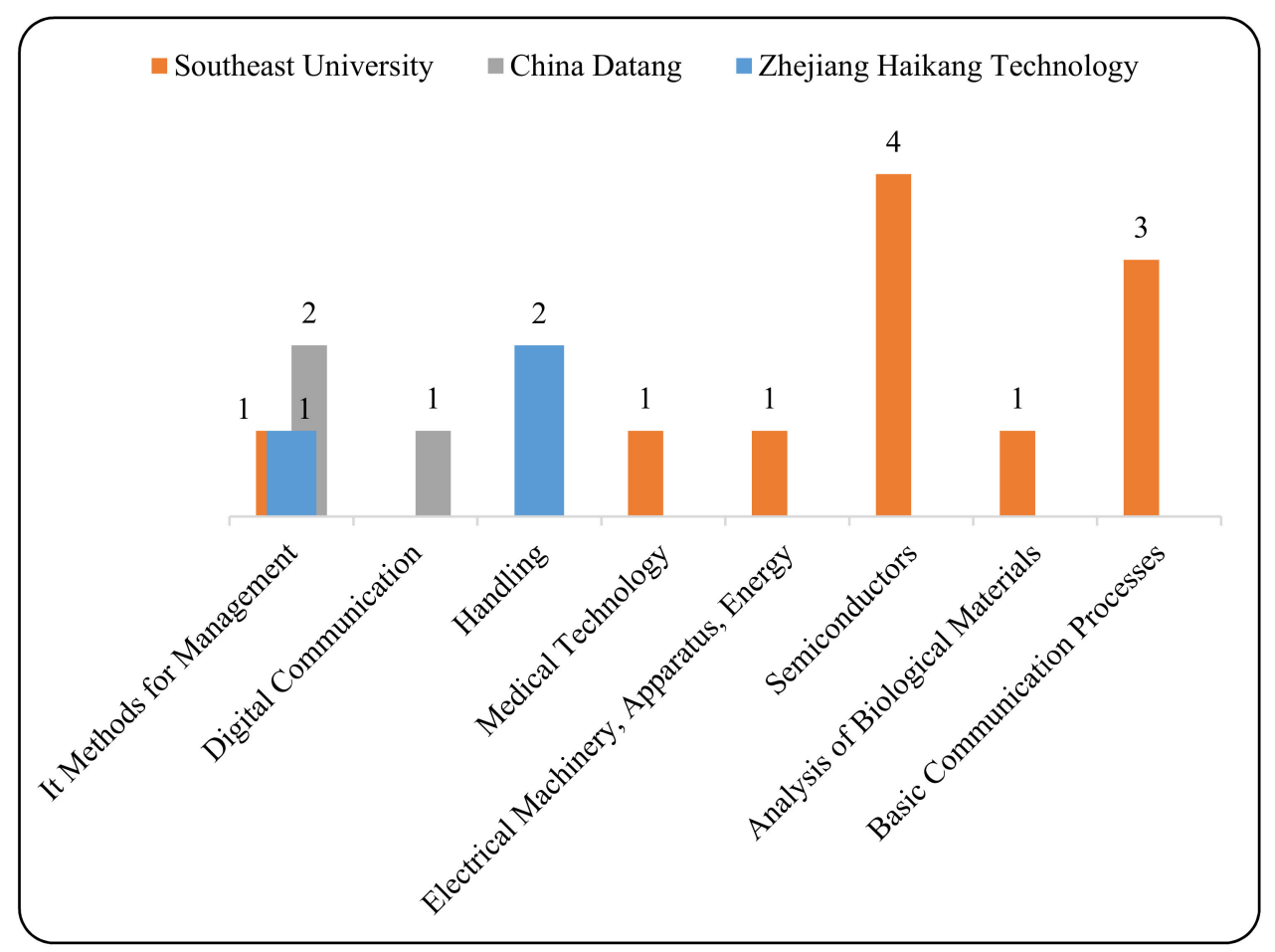

Figure 7. Patent groups from Chinese organizations. Source: Orbit (2020) [52].

The SEU was the organization that registered the most patents according to the survey. The university has filed patents in the areas of IT Methods for Management; Medical Technology; Electrical Machinery, Apparatus, Energy; Semiconductors; Analysis of Biological Materials; and Medical Technology. These patents are focused on the development of energy-conducting materials and medical monitoring of air quality [52,97]. The SEU created the National Mobile Communications Research Laboratory (CRL), which developed a collaborative network for computing architecture that uses $5 \mathrm{G}$ to send and receive data, promoting greater social connectivity [98]. Rapid data exchange enables cost savings and increased profits for organizations through the integration of processes and supply chain $[47,91,99]$.

State-owned CD operates in the civil construction and power generation sectors. The company has filed patents in the areas of IT Methods for Management and Digital Communications, aiming to improve the generation, management and distribution of wind power $[52,100]$. The $\mathrm{CD}$ coordinates research on intelligent technologies that improve energy efficiency in wind farms, reducing the impacts of power generation through coal. Increasing clean energy production through technologies that enable intelligent environments reduces the need for fossil fuels and environmental degradation [41,92,100].

The developer of controller devices ZST operates in the home appliance and industrial sectors. The organization has filed patents in the areas of IT Methods for Management and Handling. These patents aim at monitoring motorized vehicles, non-motorized vehicles, aircrafts, ships, dangerous merchandise, among others, through IoT and Radio Frequency Identification (RFID) technology, in the metropolitan area [52,101]. ZST created the "Awake" monitoring system to manage and control police equipment. This system integrates information relevant to the police force, enabling the exchange of information in police operations and the management and maintenance of equipment. The use of enabling technologies of I4.0 in public security increases the effectiveness of policing, providing greater security and reducing financial waste $[46,48,102]$.

\subsubsection{Academy}

The three universities with the highest H-Index for S4.0 are Dalian University of Technology (DUT), Beijing University of Technology (BJUT) and Chongqing University 
(CU). At DUT, there is one of the Chinese authors with the highest H-Index in the research on this topic, Dr. Joenson Z. Shyu, who researched the development of sustainability integrated with technologies that enable intelligent environments, such as CPS and IoT, to develop agriculture and manufacturing in China. The use of these technologies reduces environmental impacts and improves working conditions [31,39,103].

BJUT, together with CU, carries out studies to develop a more sustainable supply chains through the intelligent and sustainable selection of suppliers that use multi-agent technology, such as distribution, autonomy, mobility, intelligence and self-learning [56,104,105]. Authors Dr. Shan Ren and Dr. Yingfeng Zhang, affiliated with the Xi'an Institute of Posts and Telecommunications and the Shaanxi University of Technology, respectively, analyzed how the insertion of Smart Manufacturing and Big Data analysis can contribute to making sustainable intelligent production feasible. These authors developed the term Sustainable Smart Manufacturing (SSM), which implements I4.0-enabling technologies in the data analysis of Product Lifecycle Management processes. SSM transforms product-oriented life-cycle operational models into a mode that is oriented to intelligent and sustainable production [106].

\subsection{Germany}

Germany is the country with the highest H-Index (6) and with only one patent registered for this research area [51,52].

\subsubsection{Government}

To guide its technological and innovation development, the German government created the High-Tech Strategy 2025 (HTS 2025) action plan, based on economic, environmental and social growth using technologies that enable intelligent environments. It focused on three key elements: social challenges, strengthening professional skills and fostering a culture of innovation [107]. To promote urban sustainability, the German Government launched Wärmenetzsysteme 4.0, which consists of financing intelligent heating systems with the aim of preserving the environment and integrating the use of renewable energy aimed at space heating, contributing to environmental and economic sustainability in the energy sector [108].

\subsubsection{Organizations}

According to the searches carried out on the Orbit platform, the only organization in Germany that developed and registered a patent was Daimler. This patent uses Cloud Computing for sustainable management in food transport [52]. With the goal of encouraging technological innovation (registration of new patents aimed at I4.0), fairs such as the Hannover Messe (HM) are promoted, with an international physical and digital platform for the dissemination of startups and innovative technologies that emphasize Sustainability [109]. At HM it is possible to find startups and concepts geared towards agribusiness, such as the Weed Whacker, from the startup Odd.Bot, which brings a new concept of intelligent weeding to agricultural lands. This technology helps sustainable planting, increasing agricultural yields, reducing the exposure of farmworkers to toxic products and decreasing environmental degradation through intelligent machinery and sensing $[3,39,110,111]$. Its biggest differential is the application of chemical products to the crops through the Weed Whacker, mitigating the problem of contamination by chemicals harmful to health from pesticides [111,112].

The manufacturer Cybus created the software Cybus Connectware, which performs predictive monitoring and maintenance and provides a reduction in accidents and waste of inputs, increased energy efficiency and the resolution of recurring data conflict problems. The software works through intelligent sensing, IoT and Big Data [113]. This type of technology is transversal to the three pillars of the TBL, energy efficiency, reduction of accidents and reduction of input waste [31]. 


\subsubsection{Academy}

The three universities with the highest H-Index on S4.0 are the Friedrich-AlexanderUniversität Erlangen-Nürnberg (FAU), the Technical University of Berlin (TUB) and the Fraunhofer Institute for Production Systems and Design Technology IPK (FIPK). FAU has a line of research focused on technology and innovation called Digitization and Innovation, which projects and evaluates changes and innovations in the sustainability of products, processes and services based on digital technology [114]. At FAU are the three main German authors on S4.0, Prof. Dr. Julian Marius Müller, Prof. Dr. Kai-Ingo Voigt and Dr. Daniel Kiel. These authors have identified the synergistic and dissonant relationships between the use of I4.0 technologies to boost Sustainability [29,38,94,99].

The financing program for sustainable projects called "Nachhaltigkeit auf dem Bau: Berlin baut mit Holz", approved by the Berlin Chamber of Deputies, encouraged the partnership between TUB, FIPK and the company Tegel Projekt GmbH to create Bauhütte 4.0 (Building 4.0). The Bauhütte 4.0 project started investigating the potential of I4.0 to add value to sustainable urbanization, to neutralizing the increase in greenhouse gas emissions in metropolitan areas with new methods of building wood from renewable sources along with the introduction I4.0 technologies [115,116]. Projects like Bauhütte 4.0 are the result of laws and policies that reduce environmental degradation in the civil construction by using ecological materials and processes that do not harm the environment $[78,79,117]$.

\section{Opportunities and Challenges to Develop S4.0}

This section will present the main opportunities (Table 2) and challenges (Table 3) for developing S4.0 identified in the scientific literature. These conclusions were reached by analyzing scientific gaps and posing critical questions from the 30 articles that presented the highest number of citations on the topic.

Table 2. Opportunities for research on S4.0. Source: Authors.

\begin{tabular}{|c|c|}
\hline Research Opportunities & Authors \\
\hline $\begin{array}{l}\text { Identifying the impacts of the } \\
\text { Integration between Sustainability } \\
\text { and Industry } 4.0 \text { in the Supply Chain }\end{array}$ & $\begin{array}{c}\text { Bag et al. (2018) [118]; Luthra and Mangla (2018) [65]; } \\
\text { Manavalan and Jayakrishna (2019) [42]; Yazdi et al. } \\
\text { (2018) [119] }\end{array}$ \\
\hline $\begin{array}{l}\text { Proposing strategies to integrate } \\
\text { Sustainability with Industry } 4.0\end{array}$ & $\begin{array}{c}\text { Jabbour et al. (2018a) [25]; Kiel et al. (2017) [29]; Kumar } \\
\text { et al. (2018) [120]; Lin et al. (2017) [39]; Meng et al. (2018) } \\
\text { [41]; Prause and Atari (2017) [30]; Ren et al. (2019) [106]; } \\
\text { Shim et al. (2018) [121] }\end{array}$ \\
\hline $\begin{array}{l}\text { Integrating Risk Management with } \\
\text { S4.0 }\end{array}$ & Birkel et al. (2019) [99]; Ghadimi et al. (2019) [56] \\
\hline $\begin{array}{l}\text { Proposing new models of sustainable } \\
\text { production processes using the } \\
\text { technologies of Industry } 4.0\end{array}$ & $\begin{array}{c}\text { Ding (2018) [122]; Franciosi et al. (2018) [123]; } \\
\text { Garrido-Hidalgo et al. (2018) [124]; Kamble et al. (2019) } \\
\text { [84]; Prause (2015) [47] }\end{array}$ \\
\hline $\begin{array}{l}\text { Identifying and assessing the impacts } \\
\text { of implementing I4.0 on TBL }\end{array}$ & Ardanza et al. (2019) [125]; Müller and Voigt (2018) [94] \\
\hline $\begin{array}{l}\text { Identifying S4.0 contributions to } \\
\text { governments, industries and people }\end{array}$ & $\begin{array}{l}\text { Jabbour et al. (2018b) [126]; Bányai et al. (2019) [127]; } \\
\text { Batkovskiy et al. (2019) [128]; Bonilla et al. (2018) [26]; } \\
\text { Branger and Pang (2015) [48]; Haseeb et al. (2019) [33]; } \\
\text { Kamble et al. (2018) [37]; Müller et al. (2018) [38]; Stock } \\
\text { et al. (2018) [129] }\end{array}$ \\
\hline
\end{tabular}


Table 3. Challenges for the development of S4.0. Source: Authors.

\begin{tabular}{cc}
\hline Research Challenges & Authors \\
\hline $\begin{array}{c}\text { High cost for the } \\
\text { modernization/adaptation of } \\
\text { structures and intelligent technologies. }\end{array}$ & $\begin{array}{c}\text { Birkel et al. (2019) [99]; Haseeb et al. (2019) [33]; Kiel } \\
\text { et al. (2017) [29]; Lin et al. (2017) [39]; Manavalan and } \\
\text { Jayakrishna (2019) [42]; Yazdi et al. (2018) [119] }\end{array}$ \\
$\begin{array}{cc}\text { Ardanza et al. (2019) [125]; Bag et al. (2018) [118]; } \\
\text { Bonilla et al. (2018) [26]; Ding (2018) [122]; } \\
\text { Lack of company know-how and } \\
\text { qualified human capital. }\end{array}$ & $\begin{array}{c}\text { Garrido-Hidalgo et al. (2018) [124]; Ghadimi et al. } \\
\text { (2019) [56]; Kamble et al. (2018) [37]; Luthra and } \\
\text { Mangla (2018) [65]; Müller et al. (2018) [38]; Shim et al. } \\
\text { (2018) [121]; Stock et al. (2018) [129] }\end{array}$ \\
\hline Supply Chain mismatch. & $\begin{array}{c}\text { Franciosi et al. (2018) [123]; Müller and Voigt (2018) } \\
\text { [94]; Prause and Atari (2017) [30] }\end{array}$ \\
\hline Divergence of objectives between & Jabbour et al. (2018a) [25]; Kumar et al. (2018) [120] \\
sustainability and I4.0. & Bányai et al. (2019) [127]; Batkovskiy et al. (2019) [128]; \\
Lack of infrastructure. & Meng et al. (2018) [41]; Prause (2015) [47]; Ren et al. \\
(2019) [106]
\end{tabular}

In the opportunity entitled "Identifying the impacts of the Integration between Sustainability and Industry 4.0 in the Supply Chain", opportunities should be sought for the implementation of intelligent technologies that can reduce environmental impacts at each stage of the production process. To interlink the distribution chain, research that includes intellectual capital to accelerate the implementation of I4.0 in organizations should be carried out [118]. In the opportunity group "Proposing strategies to integrate Sustainability with Industry $4.0^{\prime \prime}$, research should be carried out that addresses the possibility of implementing statistical tools for the development of layouts in I4.0, considering the dimensions of sustainability to choose ideal production processes from the perspective of the TBL [120]. In the "Integrating Risk Management with S4.0" opportunity, research should be carried out to analyze and assess the risks related to the implementation of I4.0 technologies in organizations. In the environmental sphere, the risks of energy expenditure and waste must be analyzed. In the economic sphere, there are dilemmas regarding high investments that may not be converted into profitable results. As for the social issue, industries need to assess the impacts on job availability and the resistance of employees to receive adequate training for the new models of Intelligent Factories [99].

In the opportunity "Proposing new models of sustainable production processes using the technologies of Industry $4.0^{\prime \prime}$, research should be carried out to analyze how the concepts of I4.0 can improve sustainability in the environmental, economic and social spheres of manufacturing processes [123]. The results of the implementation of IoT technologies in the chemical industries should also be assessed, and if there would be impacts for the increase of sustainable productivity [122,124]. In the opportunity group "Identifying and assessing the impacts of implementing I4.0 on TBL", research should be carried out to analyze the possibilities of reducing energy consumption through Man-Machine integration. Economy of resources should also be a goal, taking advantage of machinery the organization already has, without the need to acquire technologies with high added value [125]. In the opportunity "Identifying S4.0 contributions to governments, industries and people", research should be carried out that provides, through IoT and Cloud Computing, sustainable home environments, by automating household items and integrating them into easily-managed networks. This integration reduces the consumption of gas, electric energy or photovoltaic energy, turning off equipment when they are not being used [48]. Research should also be carried out to address the implications that I4.0 may 
have for compliance with the SDGs, in relation to ecosystems, contributing to effective environmental management [26].

Fatimah et al. (2020) conducted a study that corroborates with the group "Identifying and evaluating the impacts of I4.0 implementation on TBL" through smart I4.0 technologies in the context of waste management. By using IoT and digitalization, it is possible to improve community integration from collection fields to waste industries. In this way, municipalities can achieve environmental, economic and social performance that contributes to meeting the goals. These goals are health and well-being (SDG 3); clean water and sanitation (SDG 6); decent work and economic growth (SDG 8); responsible consumption and production (SDG 12) and climate action (SDG 13) [130]. Oláh et al. (2020) agree with the opportunity group "Identifying S4.0 contributions for governments, industries and people". Thus, the importance of governments instituting well-defined policies to conserve the environment and its systems against the negative impacts of I4.0 can be reinforced [131].

In the challenge "High cost for the modernization/adaptation of structures and intelligent technologies", financial challenges must be overcome for SMEs to acquire cutting-edge technologies, lack of technological infrastructure for connection and exchange of data within the organization, and additionally overcome challenges for the implementation and development of structures with intelligent technologies [29,33,99]. In the challenge "Lack of company know-how and qualified human capital", the lack of know-how to implement I4.0 technologies creates barriers for the implementation of S4.0, as well as the lack of initial data on the benefits of I4.0 for organizational sustainability, lack of qualified workforce, and challenges to training the workforce [37,38,129]. The "Supply Chain mismatch" challenge involves the lack of knowledge of the impacts of I4.0 on the value chain, lack of infrastructure and challenges in finding suitable partners and suppliers with I4.0 technologies $[30,94,123]$.

The fourth challenge, "Divergence of objectives between sustainability and I4.0" encounters barriers to integrate a sustainable layout with an intelligent factory that meets the sustainability objectives of organizations $[25,120]$. The "Lack of infrastructure" challenge involves the difficulty in meeting the new standards for sustainability with the insertion of I4.0 and the lack of basic infrastructure for the implementation of technologies for Industry $4.0[41,47,106,128]$. In the sixth challenge, "Need for organizational alignment" the coordination of actions from different organizational areas and concerns about cybersecurity cause barriers to integrating sustainability with I4.0 [126]. Challenges in organizational alignment also pose difficulties for balancing production and high power demand with I4.0 technologies [48].

I4.0 technologies can enable efficient allocation of resources such as materials, energy and water using real-time data from production systems and supply chain partners, allowing for improved sustainability $[25,33]$. Yadav et al. (2020) mention that there is still a gap between the willingness to free trade and sustainability policies, hindering the alignment of strategic procedures in a green supply chain [64], corroborating with the cluster "Supply Chain mismatch". Tiwari and Kan (2020) cite the difficulties of investing in a structure that contemplates I4.0 technologies and also raises the possibility of "conventional" industries seeking forms of retaliation to preserve their markets [132]. Bag et al. (2021) observe that because I4.0 technologies are recent, organizations encounter many barriers to be able to implement them satisfactorily, mainly due to high costs and lack of operational structure [133].

\section{Framework for Developing S4.0}

This section presents the framework for developing S4.0 in the TH sectors (Table 4). 
Table 4. Challenges for the development of S4.0. Source: Authors.

\begin{tabular}{|c|c|c|c|}
\hline TH Sectors & Propositions & TH Connection & $\begin{array}{c}\text { Benchmarking of Scientific and Technical } \\
\text { References }\end{array}$ \\
\hline \multirow{8}{*}{ Government } & $\begin{array}{l}\text { Instituting a national program for the } \\
\text { technological and sustainable development of } \\
\text { industries. }\end{array}$ & Organizations & $\begin{array}{l}\text { Institute for Security and Development Policy } \\
\text { (2020) [96]; Müller and Voigt (2018) [94]; The } \\
\text { People's Republic of China (2020) [95] }\end{array}$ \\
\hline & $\begin{array}{l}\text { Instituting a National Plan to develop social } \\
\text { connectivity using intelligent technologies. }\end{array}$ & $\begin{array}{l}\text { Organizations and } \\
\text { Academy }\end{array}$ & $\begin{array}{l}\text { Haseeb et al. (2019) [33]; Lozano (2020) [31]; } \\
\text { Swarnima et al. (2017) [46] }\end{array}$ \\
\hline & $\begin{array}{l}\text { Improving the quality of life by monitoring air } \\
\text { quality and noise pollution, using intelligent } \\
\text { remote sensing. }\end{array}$ & Organizations & $\begin{array}{l}\text { United States Environmental Protection Agency } \\
\text { (2020b) [69] }\end{array}$ \\
\hline & $\begin{array}{c}\text { Developing plans for agricultural development, } \\
\text { solid waste management, reduction of factory } \\
\text { pollution and increased energy efficiency using } \\
\text { I4.0 technologies. }\end{array}$ & $\begin{array}{l}\text { Organizations and } \\
\text { Academy }\end{array}$ & $\begin{array}{l}\text { Borowiecki et al. (2019) [3]; Lin et al. (2017) [39]; } \\
\text { Odd.Bot (2020) [111]; Tao et al. (2016) [110] }\end{array}$ \\
\hline & $\begin{array}{l}\text { Financing projects for the development of } \\
\text { intelligent technologies and infrastructures that } \\
\text { take advantage of renewable energy for } \\
\text { sustainable development. }\end{array}$ & Academy & $\begin{array}{l}\text { Abgeordnetenhaus von Berlin (2019) [116]; } \\
\text { Bauhütte } 4.0 \text { (2020) [115] }\end{array}$ \\
\hline & $\begin{array}{c}\text { Fostering S4.0 in civil construction through tax } \\
\text { incentives. }\end{array}$ & Organizations & $\begin{array}{c}\text { Abgeordnetenhaus von Berlin (2019) [116]; } \\
\text { Bauhütte 4.0 (2020) [115]; Kisku et al. (2017) } \\
\text { [117]; Moschetti et al. (2015) [78] }\end{array}$ \\
\hline & $\begin{array}{l}\text { Creating startup financing programs to develop } \\
\text { intelligent technologies that ensure the physical } \\
\text { integrity of urban and rural workers. }\end{array}$ & $\begin{array}{l}\text { Organizations and } \\
\text { Academy }\end{array}$ & Hannover (2020) [109] \\
\hline & $\begin{array}{l}\text { Making it easier for organizations to acquire } \\
\text { intelligent structures and technologies. }\end{array}$ & Organizations & $\begin{array}{l}\text { Birkel et al. (2019) [99]; Haseeb et al. (2019) [33]; } \\
\quad \text { Kiel et al. (2017) [29]; Lin et al. (2017) [39] }\end{array}$ \\
\hline \multirow{6}{*}{ Organizations } & $\begin{array}{l}\text { Creating systems with intelligent technologies } \\
\text { to improve motor vehicle traffic and reduce } \\
\qquad \mathrm{CO}_{2} \text { emissions. }\end{array}$ & $\begin{array}{l}\text { Government and } \\
\text { Academy }\end{array}$ & $\begin{array}{c}\text { IBM, (2020b) [72]; Haseeb et al. (2019) [33]; } \\
\text { Lozano (2020) [31] }\end{array}$ \\
\hline & $\begin{array}{l}\text { Using intelligent technologies for the treatment } \\
\text { and management of water facilities. }\end{array}$ & $\begin{array}{l}\text { Government and } \\
\text { Academy }\end{array}$ & $\begin{array}{l}\text { IBM, (2020b) [72]; Haseeb et al. (2019) [33]; } \\
\text { Lozano (2020) [31] }\end{array}$ \\
\hline & $\begin{array}{l}\text { Reducing the consumption of material and } \\
\text { energy resources through digitalization, Cloud } \\
\text { Computing and IoT. }\end{array}$ & Government & $\begin{array}{l}\text { Lozano (2020) [31]; Newell and Vos (2011) [76]; } \\
\quad \text { Xerox (2020b) [74], Xerox (2020c) [75] }\end{array}$ \\
\hline & $\begin{array}{l}\text { Improving the integration of society through } \\
\text { collaborative networks with high capacity and } \\
\text { speed to exchange information in real-time. }\end{array}$ & Government & $\begin{array}{c}\text { National Mobile Communications Research } \\
\text { Laboratory (2020) [98] }\end{array}$ \\
\hline & $\begin{array}{l}\text { Implementing strategies that enable } \\
\text { organizational alignment with S4.0. }\end{array}$ & Academy & $\begin{array}{l}\text { Branger and Pang (2015) [48]; Jabbour et al. } \\
\text { (2018b) [25]; Kamble et al. (2019) [37] }\end{array}$ \\
\hline & $\begin{array}{l}\text { Using intelligent technologies to disinfect } \\
\text { biologically contaminated materials. }\end{array}$ & $\begin{array}{l}\text { Government and } \\
\text { Academy }\end{array}$ & $\begin{array}{l}\text { Chung et al. (2020) [61]; Lozano (2020) [31]; } \\
\text { VST Mobility Solutions (2020c) [59] }\end{array}$ \\
\hline \multirow{5}{*}{ Academy } & $\begin{array}{c}\text { Investigating new sources of clean energy with } \\
\text { the help of I4.0. }\end{array}$ & $\begin{array}{l}\text { Government and } \\
\text { Organizations }\end{array}$ & $\begin{array}{c}\text { Indian Institute of Technology Delhi (2020) [66]; } \\
\text { Kamble et al. (2018) [37]; Manavalan and } \\
\text { Jayakrishna (2019) [42] }\end{array}$ \\
\hline & $\begin{array}{l}\text { Developing research with I4.0 technologies that } \\
\text { enable sustainable management. }\end{array}$ & Organizations & $\begin{array}{l}\text { Bai et al. (2018) [134]; Bonilla et al. (2018) [23]; } \\
\text { Esmaeilian et al. (2020) [91] }\end{array}$ \\
\hline & $\begin{array}{l}\text { Prospecting and establishing partnerships } \\
\text { between universities and organizations that are } \\
\text { advanced in research on Industry } 4.0 \text { and } \\
\text { Sustainability. }\end{array}$ & Organizations & $\begin{array}{c}\text { Abgeordnetenhaus von Berlin, (2019) [116]; } \\
\text { Bauhütte } 4.0 \text { (2020) [115] }\end{array}$ \\
\hline & $\begin{array}{l}\text { Developing strategies and tools to integrate } \\
\text { Sustainability and Industry } 4.0 .\end{array}$ & Organizations & Kumar et al. (2018) [120] \\
\hline & $\begin{array}{l}\text { Proposing models, tools and initiatives for the } \\
\text { development of know-how and human capital } \\
\text { for S4.0. }\end{array}$ & Organizations & $\begin{array}{l}\text { Kamble et al. (2018) [37]; Müller et al. (2018) } \\
\text { [38]; Stock et al. (2018) [129] }\end{array}$ \\
\hline
\end{tabular}


For the development of S4.0 in the "Government" sector, national plans that contribute to better management of natural resources, manufactured products, waste and energy in urban and rural areas should be created. For the acquisition of sustainable intelligent technologies, financing, tax incentives and facilitation must be made available, such as term extensions and offers of subsidized interests. Public administration can also incorporate S4.0 to improve quality of life by reducing noise pollution and reducing $\mathrm{CO}_{2}$ emissions in the air. These initiatives can contribute to help achieve the SDGs proposed by the UN.

The suggested actions for the development of S4.0 in the "Organizations" sector directly contribute to public health, organizational management and Information and Communication Technology (ICT). In public health, solutions are presented to reduce $\mathrm{CO}_{2}$ emissions into the atmosphere, improve the performance of drinking water treatment and for disinfecting biologically contaminated materials. In organizational management, the focus is to align organization strategies with $\mathrm{S4} .0$ concepts and structures to meet the SDGs and increase operational efficiency. As for ICTs, the main objectives are directed to connectivity, enabling increased productivity and convenience.

Thus, the strategies and initiatives of the proposed framework must be carried out through constant interactions between the sectors of the TH. The recommendation for the integration of "Government-Organizations" is the creation of financing programs to access the technological infrastructure of S4.0. The suggestions for the integration of "GovernmentAcademy" are the development of S4.0 through the creation of research centers and the policies for financing S4.0 research. The proposition for the integration of "OrganizationsAcademy" is the creation and implementation of technologies and initiatives that enable sustainable development through I4.0 technologies. Finally, the three sectors together Government, Organizations and Academy pave the way for sustainable development, helping to overcome the global challenges posed by climate change and environmental degradation, and the difficulties for achieving responsible and safe technological progress, increasing social inclusion, among others.

I4.0 combined with sustainable development is an emerging trend that reshapes today's production and consumption patterns. However, the synergy between both depends on the know-how in intelligent technologies. The integration of these two themes deserves to be further analyzed by governments, organizations and researchers [25,33,38]. Developing countries should align their governments with startups' digitization solutions by improving their technology infrastructure conditions $[134,135]$. TH sectors should jointly plan to implement network-integrated factories. Thus, facilitating production processes, energy supply, better use of resources, among others. With this, the development of a manufacturing ecosystem is stimulated, providing the agility of products and services and efficiency in tax collection [132]. The work involving the TH sectors can also contribute to product traceability, providing information about the legality of the origin and compliance with sustainable development protocols. This tracking makes it possible to verify if economic activity does not degrade the environment, cause social imbalance or enrich criminal groups [136].

$\mathrm{TH}$ is an alternative that can make it possible for organizations to overcome barriers, enabling the exploitation of I4.0 benefits and also transforming the current production scenario into a technologically and ecologically appropriate environment $[137,138]$. However, to fully achieve this ideal world, it is necessary to review some practices of unfair competition, which concentrates productive poles in low-income countries, because the small profit margins make investments that boost the S4.0 impossible [139]. These complex solutions require the articulation of economic blocks and international organizations that align solution strategies with private sector representatives. While these actions may seem utopian at present, there are pressures from customers and global markets for ethical and sustainable performance in developing country production [140]. 


\section{Conclusions}

This article proposed a framework for developing S4.0 in the Government, Organizations and Academy sectors of the TH. Analyzing the STS-S4.0 allowed us to identify ways for I4.0 and sustainability to integrate and reach the SDGs proposed by the UN. This framework contributes to the creation of sustainable processes in organizations, sustainable growth of cities and the reduction of environmental impacts on the planet, through I4.0 technologies. The main scientific contribution of this work is to expand and deepen the recent block of knowledge on S4.0, adding strategies, initiatives, challenges and opportunities for the development of I4.0 to be aligned with sustainability. As for the applied contribution, this work contributes to the conscious and sustainable development of humanity through the technological elements of I4.0, contributing to the achievement of the following SDGs proposed by the UN: 9 (Industries, Innovation and Infrastructure), 11 (Sustainable Cities and Communities) and 13 (Climate Action). These SDGs aim to ensure, respectively, the promotion of sustainable industrialization, the creation of inclusive, safe, resilient and sustainable cities and the fight against climate change and its impacts. The main novelty of this article is the creation of paths for Government, Organizations and Academy to interactively lead the development of global sustainability through the smart technologies of I4.0. Thus these three sectors can enhance their actions to promote S4.0, providing more and better solutions to the challenges of sustainable development.

The results of this article are limited to the databases and country selection criteria (H-Index articles and Patents). The ranking of the countries based on the adopted criteria showed that both developed and developing countries are seeking to use I4.0 technologies to contribute to sustainability, which demonstrates that countries that are not necessarily world leaders in I4.0 or in sustainability may have prominent S4.0 initiatives. However, the authors of this work recognize that the ranking does not include all the prominent countries in S4.0, but rather those that quantitatively had the best performance in the indicators of H-Index (articles) and Patents registered. Thus, it is worth mentioning that the results of this paper do not portray the proposition of systemic recommendations to S4.0 development, but rather a framework of good practices that can be added to other initiatives in future studies or even in a new framework. Future studies could consider other research criteria and indicators, for example, the number of H-Index (articles) and Patents per capita, and may result in a different ranking composed of other countries, organizations and research institutions that will probably make it possible to identify other policies and initiatives to be added in the framework proposed in this paper. Trend studies on the use of technologies such as Autonomy, IoT, AI, RFID and others to reduce waste, increase reliability and improve process quality are also recommended.

Author Contributions: Conceptualization, O.J.d.O., J.S.d.M.R. and M.E.; methodology, O.J.d.O., F.C.d.C., J.S.d.M.R., M.E. and T.V.N.; software, J.S.d.M.R. and M.E.; validation, O.J.d.O. and R.I.; formal analysis, J.S.d.M.R., M.E., T.V.N. and N.A.d.S.S.; investigation, J.S.d.M.R.; resources, O.J.d.O., J.S.d.M.R. and R.I.; data curation, J.S.d.M.R.; writing—original draft preparation, J.S.d.M.R.; writingreview and editing, O.J.d.O., F.C.d.C., R.I. and N.A.d.S.S.; supervision, O.J.d.O.; project administration, J.S.d.M.R.; funding acquisition, O.J.d.O. and R.I. Please turn to the CRediT taxonomy for the term explanation. Authorship must be limited to those who have contributed substantially to the work reported. All authors have read and agreed to the published version of the manuscript.

Funding: This study was funded in part by the Coordenação de Aperfeiçoamento de Pessoal de Nível Superior-Brazil (CAPES)—Financial Code 001, CNPq-Conselho Nacional de Desenvolvimento Científico e Tecnológico-(312894/2017-1 and 312538/2020-0) and the Fundação de Amparo à Pesquisa do Estado de São Paulo [Grant numbers 2016/20160-0, 2017/18304-7 and 2019/08750-5] for financial support.

Data Availability Statement: Data sharing not applicable. No new data were created or analyzed in this study. Data sharing is not applicable to this article.

Conflicts of Interest: The authors declare no conflict of interest. 


\section{Appendix A}

Table A1. Most Cited Countries.

\begin{tabular}{|c|c|c|c|c|c|c|c|c|c|c|c|}
\hline \multirow[b]{2}{*}{ Countries, H-Index } & \multirow{2}{*}{$\begin{array}{c}\text { Total Citations- } \\
\text { Documents }\end{array}$} & \multicolumn{5}{|c|}{ Citations } & \multicolumn{5}{|c|}{ Documents } \\
\hline & & 党 & 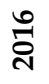 & 옹 & $\stackrel{\infty}{\stackrel{\infty}{*}}$ & $\stackrel{\text { )े }}{\text { ) }}$ & 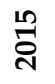 & ?: & 옥 & $\stackrel{\infty}{\stackrel{\sim}{*}}$ & $\overrightarrow{\vec{s}}$ \\
\hline Germany, 6 & $220-6$ & $\mathbf{0}$ & $\mathbf{0}$ & $\begin{array}{l}4 \\
-\end{array}$ & $\begin{array}{l}70 \\
\square\end{array}$ & 146 & $\mathbf{0}$ & $\mathbf{0}$ & 2 & 3 & 1 \\
\hline India, 5 & $109-9$ & $\mathbf{0}$ & $\mathbf{0}$ & $\mathbf{0}$ & $\begin{array}{l}11 \\
-\end{array}$ & 98 & $\mathbf{0}$ & $\mathbf{0}$ & $\mathbf{0}$ & 4 & 5 \\
\hline Brazil, 4 & $151-6$ & $\mathbf{0}$ & $\mathbf{0}$ & $\mathbf{0}$ & $\begin{array}{c}25 \\
-\end{array}$ & $\begin{array}{c}126 \\
\square\end{array}$ & $\mathbf{0}$ & $\mathbf{0}$ & $\mathbf{0}$ & 3 & 3 \\
\hline United States of America, 4 & $86-13$ & $\mathbf{0}$ & $\mathbf{0}$ & $\mathbf{0}$ & $\begin{array}{l}5 \\
-\end{array}$ & 81 & $\mathbf{0}$ & $\mathbf{0}$ & $\mathbf{0}$ & 2 & 11 \\
\hline France, 3 & $110-3$ & $\mathbf{0}$ & $\mathbf{0}$ & $\mathbf{0}$ & 23 & 87 & $\mathbf{0}$ & 0 & $\mathbf{0}$ & 3 & $\mathbf{0}$ \\
\hline China, 3 & $47-3$ & $\mathbf{0}$ & $\mathbf{0}$ & $\mathbf{0}$ & $\begin{array}{l}9 \\
-\end{array}$ & 38 & $\mathbf{0}$ & $\mathbf{0}$ & $\begin{array}{l}1 \\
\square\end{array}$ & $\mathbf{0}$ & 2 \\
\hline United Kingdom, 3 & $46-6$ & $\mathbf{0}$ & $\mathbf{0}$ & $\mathbf{0}$ & $\begin{array}{l}7 \\
-\end{array}$ & 39 & $\mathbf{0}$ & $\mathbf{0}$ & $\mathbf{0}$ & 2 & 4 \\
\hline Malaysia, 2 & $111-3$ & $\mathbf{0}$ & $\mathbf{0}$ & $\mathbf{0}$ & $\mathbf{0}$ & 111 & $\mathbf{0}$ & $\mathbf{0}$ & $\mathbf{0}$ & $\mathbf{0}$ & 3 \\
\hline Estonia, 2 & $70-2$ & 0 & $\frac{3}{-}$ & 12 & 31 & $\begin{array}{l}24 \\
\square\end{array}$ & 1 & 0 & 1 & $\mathbf{0}$ & 0 \\
\hline Sweden, 2 & $54-3$ & $\mathbf{0}$ & 1 & 9 & $\begin{array}{r}7 \\
-\end{array}$ & 37 & 1 & $\mathbf{0}$ & $\mathbf{0}$ & $\mathbf{0}$ & 2 \\
\hline
\end{tabular}




\section{Appendix B}

Table A2. Most Cited Articles.

\begin{tabular}{|c|c|c|c|c|c|c|c|c|c|c|c|}
\hline \multirow[b]{2}{*}{$\#$} & \multirow[b]{2}{*}{ Title } & \multirow[b]{2}{*}{$\begin{array}{l}\text { Authors } \\
\text { (Year) }\end{array}$} & \multirow[b]{2}{*}{$\begin{array}{c}\text { Journal } \\
\text { (ISSN) }\end{array}$} & \multirow[b]{2}{*}{ Opportunities } & \multirow[b]{2}{*}{ Challenges } & \multirow{2}{*}{$\begin{array}{c}\text { Total } \\
\text { Citations } \\
(\mathbf{1 8 / 0 2 / 2 0 )}\end{array}$} & \multicolumn{5}{|c|}{ Evolution of Citations } \\
\hline & & & & & & & $\stackrel{\operatorname{Ln}}{\mathrm{n}}$ & 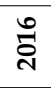 & $\hat{\text { ลे }}$ & $\stackrel{\infty}{\stackrel{\sim}{*}}$ & 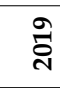 \\
\hline 1 & $\begin{array}{c}\text { Industry 4.0: A Solution Towards } \\
\text { Technology Challenges Of Sustainable } \\
\text { Business Performance }\end{array}$ & $\begin{array}{l}\text { Haseeb et al. } \\
\text { (2019) [33] }\end{array}$ & $\begin{array}{l}\text { Social Sciences } \\
\quad(2076-0760)\end{array}$ & $\begin{array}{l}\text { Mapping How Industry 4.0 Is } \\
\text { Benefiting Sustainable } \\
\text { Performance In Multinationals }\end{array}$ & $\begin{array}{l}\text { Financial Challenges For SMEs } \\
\text { To Acquire Cutting-Edge } \\
\text { Technologies }\end{array}$ & 109 & $\mathbf{0}$ & $\mathbf{0}$ & 0 & & 109 \\
\hline 2 & $\begin{array}{l}\text { What drives the implementation of } \\
\text { industry } 4.0 \text { ? The role of opportunities } \\
\text { and challenges in the context of } \\
\text { sustainability }\end{array}$ & $\begin{array}{l}\text { Müller et al. } \\
\text { (2018) [38] }\end{array}$ & $\begin{array}{l}\text { Sustainability } \\
(2071-1050)\end{array}$ & $\begin{array}{l}\text { Analyze The Benefits Of } \\
\text { Industry } 4.0 \text { Within The Field Of } \\
\text { Sustainability }\end{array}$ & $\begin{array}{c}\text { Lack Of Know-How For } \\
\text { Implementing Industry } 4.0 \\
\text { Technologies }\end{array}$ & 75 & 0 & $\mathbf{0}$ & 0 & & 53 \\
\hline 3 & $\begin{array}{l}\text { When titans meet - can industry } 4.0 \\
\text { revolutionise the } \\
\text { environmentally-sustainable } \\
\text { manufacturing wave? The role of critical } \\
\text { success factors }\end{array}$ & $\begin{array}{l}\text { Jabbour et al. } \\
\text { (2018a) [25] }\end{array}$ & $\begin{array}{l}\text { Technological } \\
\text { Forecasting And Social } \\
\text { Change } \\
(0040-1625)\end{array}$ & $\begin{array}{l}\text { Identify The Synergies And } \\
\text { Dissonances Between Industry } \\
4.0 \text { And Sustainability }\end{array}$ & $\begin{array}{c}\text { Challenges In Integrating } \\
\text { Industry } 4.0 \text { With Organizations } \\
\text { Sustainability Goals }\end{array}$ & 54 & 0 & 0 & & & \\
\hline 4 & $\begin{array}{c}\text { Industry } 4.0 \text { And The Circular Economy: } \\
\text { A Proposed Research Agenda And } \\
\text { Original Roadmap For Sustainable } \\
\text { Operations }\end{array}$ & $\begin{array}{l}\text { Jabbour et al. } \\
(2018 b)[126]\end{array}$ & $\begin{array}{l}\text { Annals Of Operations } \\
\text { Research } \\
(0254-5330)\end{array}$ & $\begin{array}{c}\text { Propose Best Practices With } \\
\text { Industry 4.0 Technologies That } \\
\text { Enhance Circular Economy In } \\
\text { Organizations }\end{array}$ & $\begin{array}{l}\text { Coordinate Actions In Different } \\
\text { Organizational Areas And } \\
\text { Cybersecurity Concerns }\end{array}$ & 49 & $\mathbf{0}$ & $\mathbf{0}$ & $\mathbf{0}$ & & \\
\hline 5 & $\begin{array}{l}\text { Sustainable Industrial Value Creation: } \\
\text { Benefits And Challenges Of Industry } 4.0\end{array}$ & $\begin{array}{l}\text { Kiel et al. } \\
\text { (2017) [29] }\end{array}$ & $\begin{array}{c}\text { International Journal Of } \\
\text { Innovation Management } \\
\text { (1363-9196) }\end{array}$ & $\begin{array}{l}\text { Measure The Cost Benefit Of } \\
\text { Integrating Industry } 4.0 \text { And } \\
\text { Sustainability }\end{array}$ & $\begin{array}{l}\text { High Cost To Adapt The } \\
\text { Technological Infrastructure For } \\
\text { Connection And Data Exchange } \\
\text { Within The Organization }\end{array}$ & 48 & $\mathbf{0}$ & 0 & & & 25 \\
\hline 6 & $\begin{array}{c}\text { Sustainable Industry 4.0 Framework: A } \\
\text { Systematic Literature Review Identifying } \\
\text { The Current Trends And Future } \\
\text { Perspectives }\end{array}$ & $\begin{array}{c}\text { Kamble et al. } \\
\text { (2018) [37] }\end{array}$ & $\begin{array}{l}\text { Process Safety And } \\
\text { Environmental } \\
\text { Protection } \\
(0957-5820)\end{array}$ & $\begin{array}{l}\text { Identify Trends In Scientific } \\
\text { Research On Sustainable } \\
\text { Industry } 4.0\end{array}$ & $\begin{array}{l}\text { Lack Of Initial Data On The } \\
\text { Benefits Of Industry 4.0 For } \\
\text { Organizational Sustainability }\end{array}$ & 46 & 0 & 0 & $\mathbf{0}$ & & \\
\hline 7 & $\begin{array}{l}\text { Sustainable Business Models And } \\
\text { Structures For Industry 4.0 }\end{array}$ & $\begin{array}{l}\text { Prause } \\
\text { (2015) [47] }\end{array}$ & $\begin{array}{l}\text { Journal Of Security And } \\
\text { Sustainability Issues } \\
\text { (2029-7017) }\end{array}$ & $\begin{array}{l}\text { Identify Opportunities For New } \\
\text { Sustainable Business Models In } \\
\text { The Industrie 4.0 Age }\end{array}$ & $\begin{array}{l}\text { Challenges With The New } \\
\text { Normalizations For } \\
\text { Sustainability With The } \\
\text { Insertion Of Industry } 4.0\end{array}$ & 37 & 0 & & & 12 & 14 \\
\hline 8 & $\begin{array}{l}\text { Evaluating Challenges To Industry } 4.0 \\
\text { Initiatives For Supply Chain } \\
\text { Sustainability In Emerging Economies }\end{array}$ & $\begin{array}{l}\text { Luthra and } \\
\text { Mangla } \\
\text { (2018) [65] }\end{array}$ & $\begin{array}{l}\text { Process Safety And } \\
\text { Environmental } \\
\text { Protection } \\
(0957-5820)\end{array}$ & $\begin{array}{c}\text { Investigate The Impacts On } \\
\text { Sustainability In Emerging } \\
\text { Economies That Have } \\
\text { Implemented Industry } 4.0 \text { In } \\
\text { Supply Chains }\end{array}$ & $\begin{array}{l}\text { Lack Of Knowledge Of The } \\
\text { Impacts Of Industry } 4.0 \text { For } \\
\text { Sustainability }\end{array}$ & 33 & 0 & 0 & $\mathbf{0}$ & & 27 \\
\hline
\end{tabular}


Table A2. Cont.

\begin{tabular}{|c|c|c|c|c|c|c|c|c|c|c|c|}
\hline \multirow[b]{2}{*}{$\#$} & \multirow[b]{2}{*}{ Title } & \multirow[b]{2}{*}{$\begin{array}{l}\text { Authors } \\
\text { (Year) }\end{array}$} & \multirow[b]{2}{*}{$\begin{array}{c}\text { Journal } \\
\text { (ISSN) }\end{array}$} & \multirow[b]{2}{*}{ Opportunities } & \multirow[b]{2}{*}{ Challenges } & \multirow{2}{*}{$\begin{array}{c}\text { Total } \\
\text { Citations } \\
(\mathbf{1 8 / 0 2 / 2 0 )}\end{array}$} & \multicolumn{5}{|c|}{ Evolution of Citations } \\
\hline & & & & & & & 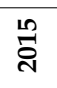 & 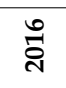 & $\hat{\text { กิ }}$ & $\stackrel{\infty}{\stackrel{2}{2}}$ & 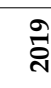 \\
\hline 9 & $\begin{array}{l}\text { On Sustainable Production Networks For } \\
\text { Industry } 4.0\end{array}$ & $\begin{array}{l}\text { Prause and } \\
\text { Atari (2017) } \\
\text { [30] }\end{array}$ & $\begin{array}{l}\text { Entrepreneurship And } \\
\text { Sustainability Issues } \\
\quad(2345-0282)\end{array}$ & $\begin{array}{l}\text { Evaluate The Benefits For } \\
\text { Sustainability In Implementing } \\
\text { Industry } 4.0 \text { Technologies }\end{array}$ & $\begin{array}{l}\text { Lack Of Infrastructure For } \\
\text { Integration Of Value Chains }\end{array}$ & 33 & 0 & 0 & & & \\
\hline 10 & $\begin{array}{c}\text { From Automated Home To Sustainable, } \\
\text { Healthy And Manufacturing Home: A } \\
\text { New Story Enabled By The } \\
\text { Internet-Of-Things And Industry } 4.0\end{array}$ & $\begin{array}{l}\text { Branger and } \\
\text { Pang (2015) } \\
\quad[48]\end{array}$ & $\begin{array}{c}\text { Journal Of Management } \\
\text { Analytics } \\
(2327-0012)\end{array}$ & $\begin{array}{c}\text { Identify Opportunities To Make } \\
\text { People's Daily Lives More } \\
\text { Sustainable Through Industry } \\
4.0\end{array}$ & $\begin{array}{c}\text { Difficulty In Balancing } \\
\text { Production And High Energy } \\
\text { Demand With Industry } 4.0 \\
\text { Technologies }\end{array}$ & 29 & 0 & & 9 & & 12 \\
\hline 11 & $\begin{array}{l}\text { Industry 4.0 As Enabler For A Sustainable } \\
\text { Development: A Qualitative Assessment } \\
\text { Of Its Ecological And Social Potential }\end{array}$ & $\begin{array}{l}\text { Stock et al. } \\
\text { (2018) [129] }\end{array}$ & $\begin{array}{l}\text { Process Safety And } \\
\text { Environmental } \\
\text { Protection } \\
(0957-5820)\end{array}$ & $\begin{array}{c}\text { Evaluate The Sustainable } \\
\text { Potential Of Industry 4.0 Within } \\
\text { Organizations }\end{array}$ & $\begin{array}{l}\text { Lack Of Skilled Labor And } \\
\text { Challenges In Specializing The } \\
\text { Labor Force }\end{array}$ & 27 & 0 & 0 & $\mathbf{0}$ & & 24 \\
\hline 12 & $\begin{array}{c}\text { A Comprehensive Review Of Big Data } \\
\text { Analytics Throughout Product Lifecycle } \\
\text { To Support Sustainable Smart } \\
\text { Manufacturing: A Framework, } \\
\text { Challenges And Future Research } \\
\text { Directions }\end{array}$ & $\begin{array}{l}\text { Ren et al. } \\
\text { (2019) [106] }\end{array}$ & $\begin{array}{l}\text { Journal Of Cleaner } \\
\text { Production } \\
\text { (0959-6526) }\end{array}$ & $\begin{array}{c}\text { Measuring the impact of } \\
\text { industry } 4.0 \text { technologies } \\
\text { (cyber-physical systems etc.) On } \\
\text { sustainability }\end{array}$ & $\begin{array}{l}\text { Lack Of Adequate Data } \\
\text { Management Infrastructure }\end{array}$ & 25 & 0 & 0 & 0 & & 25 \\
\hline 13 & $\begin{array}{l}\text { Sustainable Industrial Value Creation In } \\
\text { SMEs: A Comparison Between Industry } \\
4.0 \text { And Made In China } 2025\end{array}$ & $\begin{array}{l}\text { Müller and } \\
\text { Voigt (2018) } \\
\quad[94]\end{array}$ & $\begin{array}{c}\text { International Journal Of } \\
\text { Precision Engineering } \\
\text { And } \\
\text { Manufacturing-Green } \\
\text { Technology } \\
(2288-6206)\end{array}$ & $\begin{array}{c}\text { Identify Which Jobs Have } \\
\text { Emerged And Which Will Be } \\
\text { Discontinued With Industry } 4.0\end{array}$ & $\begin{array}{l}\text { Challenges In Finding Suitable } \\
\text { Partners And Suppliers With } \\
\text { Industry } 4.0 \text { Technologies }\end{array}$ & 25 & 0 & 0 & 0 & & 22 \\
\hline 14 & $\begin{array}{l}\text { Industry } 4.0 \text { And Sustainability } \\
\text { Implications: A Scenario-Based Analysis } \\
\text { Of The Impacts And Challenges }\end{array}$ & $\begin{array}{l}\text { Bonilla et al. } \\
\text { (2018) [26] }\end{array}$ & $\begin{array}{l}\text { Sustainability } \\
(2071-1050)\end{array}$ & $\begin{array}{l}\text { Identify Opportunities For } \\
\text { Industry 4.0's Contribution To } \\
\text { Environmental Sustainability }\end{array}$ & $\begin{array}{l}\text { Lack Of Knowledge Of Industry } \\
\text { 4.0 Technologies }\end{array}$ & 22 & 0 & $\mathbf{0}$ & $\mathbf{0}$ & & 20 \\
\hline 15 & $\begin{array}{l}\text { A Cross-Strait Comparison Of Innovation } \\
\text { Policy Under Industry 4.0 And } \\
\text { Sustainability Development Transition }\end{array}$ & $\begin{array}{l}\text { Lin et al. } \\
\text { (2017) [39] }\end{array}$ & $\begin{array}{l}\text { Sustainability } \\
(2071-1050)\end{array}$ & $\begin{array}{c}\text { Propose New Strategic } \\
\text { Interactions Between Industry } \\
4.0 \text { And Sustainability }\end{array}$ & $\begin{array}{l}\text { Propose New Interactions } \\
\text { Between Industry } 4.0 \text { And } \\
\text { Corporate Sustainability }\end{array}$ & 18 & 0 & 0 & & & 9 \\
\hline 16 & $\begin{array}{c}\text { Development Of A Risk Framework For } \\
\text { Industry 4.0 In The Context Of } \\
\text { Sustainability For Established } \\
\text { Manufacturers }\end{array}$ & $\begin{array}{l}\text { Birkel et al. } \\
\text { (2019) [99] }\end{array}$ & $\begin{array}{l}\text { Sustainability } \\
(2071-1050)\end{array}$ & $\begin{array}{l}\text { Investigate Opportunities In } \\
\text { Industry 4.0 Management Risks } \\
\text { Related To Sustainability }\end{array}$ & $\begin{array}{c}\text { High Costs With Long And } \\
\text { Unclear Amortization With The } \\
\text { Implementation Of Industry } 4.0 \\
\text { Technologies }\end{array}$ & 12 & 0 & $\mathbf{0}$ & $\mathbf{0}$ & & 12 \\
\hline
\end{tabular}


Table A2. Cont.

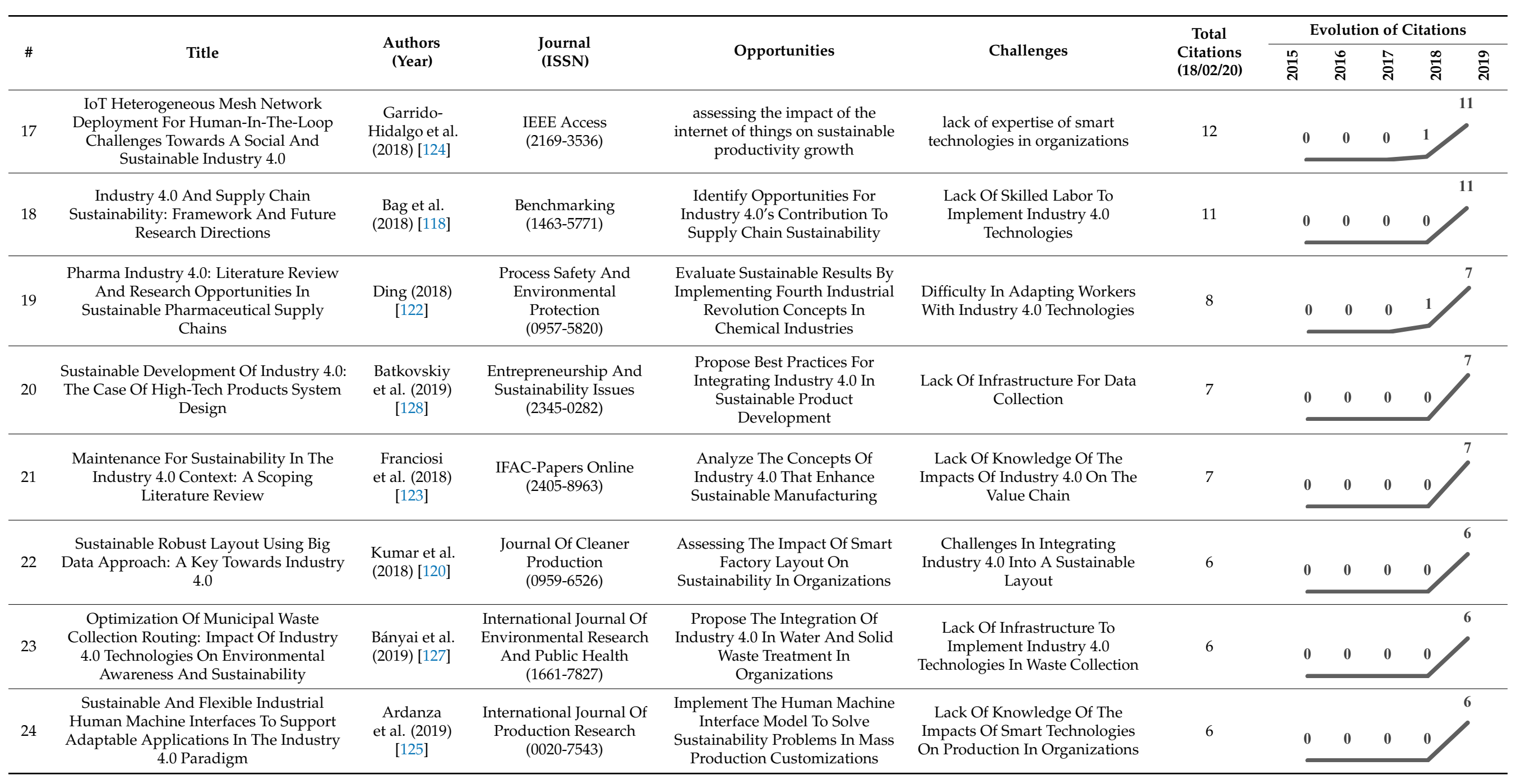


Table A2. Cont.

\begin{tabular}{|c|c|c|c|c|c|c|c|c|c|c|c|}
\hline \multirow[b]{2}{*}{$\#$} & \multirow[b]{2}{*}{ Title } & \multirow[b]{2}{*}{$\begin{array}{l}\text { Authors } \\
\text { (Year) }\end{array}$} & \multirow[b]{2}{*}{$\begin{array}{l}\text { Journal } \\
\text { (ISSN) }\end{array}$} & \multirow[b]{2}{*}{ Opportunities } & \multirow[b]{2}{*}{ Challenges } & \multirow{2}{*}{$\begin{array}{l}\text { Total } \\
\text { Citations } \\
(\mathbf{1 8 / 0 2 / 2 0 )}\end{array}$} & \multicolumn{5}{|c|}{ Evolution of Citations } \\
\hline & & & & & & & 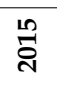 & $\stackrel{\text { ஸ̊ }}{2}$ & $\hat{\text { กิ }}$ & $\stackrel{\infty}{\stackrel{N}{*}}$ & 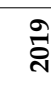 \\
\hline 25 & $\begin{array}{l}\text { Enhancing Sustainability And Energy } \\
\text { Efficiency In Smart Factories: A Review }\end{array}$ & $\begin{array}{l}\text { Meng et al. } \\
\text { (2018) [41] }\end{array}$ & $\begin{array}{l}\text { Sustainability } \\
(2071-1050)\end{array}$ & $\begin{array}{c}\text { Map The Concepts Of Industry } \\
4.0 \text { That Contribute To } \\
\text { Sustainability }\end{array}$ & $\begin{array}{l}\text { Lack Of Basic Infrastructure To } \\
\text { Implement Industry } 4.0 \\
\text { Technologies }\end{array}$ & 6 & 0 & $\mathbf{0}$ & $\mathbf{0}$ & & 6 \\
\hline 26 & $\begin{array}{c}\text { Industry 4.0 And Lean Manufacturing } \\
\text { Practices For Sustainable Organisational } \\
\text { Performance In Indian Manufacturing } \\
\text { Companies }\end{array}$ & $\begin{array}{l}\text { Kamble et al. } \\
\text { (2019) [84] }\end{array}$ & $\begin{array}{l}\text { International Journal Of } \\
\text { Production Research } \\
\text { (0020-7543) }\end{array}$ & $\begin{array}{l}\text { Identify The Synergies And } \\
\text { Dissonances Between Industry } \\
\text { 4.0 And Lean Manufacturing In } \\
\text { The Context Of Sustainability }\end{array}$ & $\begin{array}{c}\text { Weak Administrative Support, } \\
\text { Low Awareness, Reluctant } \\
\text { Behavior And Lack Of } \\
\text { Competence } \\
\end{array}$ & 5 & 0 & $\mathbf{0}$ & $\mathbf{0}$ & & 5 \\
\hline 27 & $\begin{array}{l}\text { A Review Of Internet Of Things (IoT) } \\
\text { Embedded Sustainable Supply Chain For } \\
\text { Industry 4.0 Requirements }\end{array}$ & $\begin{array}{l}\text { Manavalan } \\
\text { and } \\
\text { Jayakrishna } \\
\text { (2019) [42] }\end{array}$ & $\begin{array}{l}\text { Computers And } \\
\text { Industrial Engineering } \\
(0360-8352)\end{array}$ & $\begin{array}{l}\text { Identifying Synergies And } \\
\text { Dissonances When } \\
\text { Implementing The Internet Of } \\
\text { Things In Supply Chain } \\
\text { Management }\end{array}$ & $\begin{array}{l}\text { Financial Challenges To } \\
\text { Implement Industry } 4.0 \\
\text { Technologies }\end{array}$ & 5 & $\mathbf{0}$ & $\mathbf{0}$ & $\mathbf{0}$ & & 5 \\
\hline 28 & $\begin{array}{l}\text { Sustainable Production Scheduling In } \\
\text { Open Innovation Perspective Under The } \\
\text { Fourth Industrial Revolution }\end{array}$ & $\begin{array}{l}\text { Shim et al. } \\
\text { (2018) [121] }\end{array}$ & $\begin{array}{c}\text { Journal Of Open } \\
\text { Innovation: Technology, } \\
\text { Market And Complexity } \\
\quad(2199-8531)\end{array}$ & $\begin{array}{l}\text { Assess The Impact On } \\
\text { Sustainability By Implementing } \\
\text { Industry 4.0 Concepts In } \\
\text { Production Scheduling }\end{array}$ & $\begin{array}{l}\text { Lack Of Knowledge About The } \\
\text { Impacts Of Industry 4.0 On } \\
\text { Organizations }\end{array}$ & 5 & $\mathbf{0}$ & $\mathbf{0}$ & $\mathbf{0}$ & & 5 \\
\hline 29 & $\begin{array}{l}\text { An Empirical Investigation Of The } \\
\text { Relationship Between Overall Equipment } \\
\text { Efficiency (OEE) And Manufacturing } \\
\text { Sustainability In Industry 4.0 With Time } \\
\text { Study Approach }\end{array}$ & $\begin{array}{l}\text { Yazdi et al. } \\
\text { (2018) [119] }\end{array}$ & $\begin{array}{l}\text { Sustainability } \\
(2071-1050)\end{array}$ & $\begin{array}{c}\text { Identify integration } \\
\text { opportunities between industry } \\
4.0 \text { technologies (cyber-physical } \\
\text { systems etc.) And supply chain } \\
\text { management }\end{array}$ & $\begin{array}{l}\text { High Investment To Implement } \\
\text { Industry } 4.0 \text { Technologies }\end{array}$ & 5 & $\mathbf{0}$ & $\mathbf{0}$ & $\mathbf{0}$ & & 5 \\
\hline 30 & $\begin{array}{c}\text { Intelligent Sustainable Supplier Selection } \\
\text { Using Multi-Agent Technology: Theory } \\
\text { And Application For Industry 4.0 Supply } \\
\text { Chains }\end{array}$ & $\begin{array}{l}\text { Ghadimi } \\
\text { et al. }(2019) \\
{[56]}\end{array}$ & $\begin{array}{l}\text { Computers And } \\
\text { Industrial Engineering } \\
(0360-8352)\end{array}$ & $\begin{array}{l}\text { Assessing The Risks In The } \\
\text { Transition From An Ordinary } \\
\text { Factory To A Smart Factory }\end{array}$ & $\begin{array}{l}\text { Lack Of Expertise In Industry } \\
4.0 \text { Technologies }\end{array}$ & 4 & 0 & $\mathbf{0}$ & $\mathbf{0}$ & & \\
\hline
\end{tabular}




\section{References}

1. United Nations Sustainable Development Goals. Available online: https://www.un.org/sustainabledevelopment/sustainabledevelopment-goals / (accessed on 16 June 2020).

2. World Health Organization. Available online: https://www.who.int/heli/risks/en/ (accessed on 16 June 2020).

3. Borowiecki, M.; Machado, D.; Paunov, C.; Planes-Satorra, S. Supporting Research for Sustainable Development; OECD Science, Technology and Industry Policy Papers; OECD iLibrary: Paris, France, 2019; 71p. [CrossRef]

4. Elkington, J. Accounting for the Triple Bottom Line. Meas. Bus. Excell. 1998, 2, 18-22. [CrossRef]

5. Klewitz, J.; Hansen, E.G. Sustainability-oriented innovation of SMEs: A systematic review. J. Clean. Prod. 2014, 65, 57-75. [CrossRef]

6. Isaksson, R. Creating a sense of urgency for sustainable development-Testing two system models. J. Clean. Prod. 2019, 227, 1173-1184. [CrossRef]

7. Isaksson, R.; Buregyeya, A. Understanding sustainability-The case of building blocks in Tanzania and Uganda. TQM J. 2020. [CrossRef]

8. Cöster, M.; Dahlin, G.; Isaksson, R. Are They Reporting the Right Thing and Are They Doing It Right?-A Measurement Maturity Grid for Evaluation of Sustainability Reports. Sustainability 2020, 12, 10393. [CrossRef]

9. United Nations Transforming our world: The 2030 Agenda for Sustainable Development. Available online: https://www.un.org/ ga/search/view_doc.asp?symbol=A/RES/70/1\&Lang=E (accessed on 16 June 2020).

10. United Nations Page and The Sustainable Development Goals. Available online: https://www.un-page.org/page-andsustainable-development-goals (accessed on 16 June 2020).

11. World Economic Forum. Davos Manifesto 2020: The Universal Purpose of a Company in the Fourth Industrial Revolution. Available online: https://www.weforum.org/agenda/2019/10/davos-2020-wef-world-economic-forum-theme/ (accessed on 15 June 2020).

12. Bonavolonta, F.; Tedesco, A.; Moriello, R.S.L.; Tufano, A. Enabling wireless technologies for industry 4.0: State of the art. In Proceedings of the 2017 IEEE International Workshop on Measurement and Networking (M\&N), Naples, Italy, 27-29 September 2017.

13. Thoben, K.; Wiesner, S.; Wuest, T. "Industrie 4.0" and Smart Manufacturing-A Review of Research Issues and Application Examples. Int. J. Autom. Technol. 2017, 11, 4-16. [CrossRef]

14. Roblek, V.; Meško, M.; Krapež, A. A Complex View of Industry 4.0. SAGE Open 2016, 6, 215824401665398. [CrossRef]

15. Ciffolilli, A.; Muscio, A. Industry 4.0: National and regional comparative advantages in key enabling technologies. Eur. Plan. Stud. 2018, 26, 2323-2343. [CrossRef]

16. Bigliardi, B.; Bottani, E.; Casella, G. Enabling technologies, application areas and impact of industry 4.0: A bibliographic analysis Procedia Manuf. 2020, 42, 322-326. [CrossRef]

17. Bortolini, M.; Ferrari, E.; Gamberi, M.; Pilati, F.; Faccio, M. Assembly system design in the Industry 4.0 era: A general framework. IFAC PapersOnLine 2017, 50, 5700-5705. [CrossRef]

18. Xu, L.D.; Xu, E.L.; Li, L. Industry 4.0: State of the art and future trends. Int. J. Prod. Res. 2018, 56, 2941-2962. [CrossRef]

19. Kang, H.S.; Lee, J.Y.; Choi, S.; Kim, H.; Park, J.H.; Son, J.Y.; Kim, B.H.; Noh, S. Do Smart manufacturing: Past research, present findings, and future directions. Int. J. Precis. Eng. Manuf. Technol. 2016, 3, 111-128. [CrossRef]

20. IIConsortium. The Industrial Internet Consortium: A Global Nonprofit Partnership Of Industry, Government and Academia. Available online: https:/ / www.iiconsortium.org/about-us.htm (accessed on 23 June 2020).

21. Li, L. China's manufacturing locus in 2025: With a comparison of "Made-in-China 2025" and "Industry 4.0.". Technol. Forecast. Soc. Chang. 2018, 135, 66-74. [CrossRef]

22. Bai, C.; Dallasega, P.; Orzes, G.; Sarkis, J. Industry 4.0 technologies assessment: A sustainability perspective. Int. J. Prod. Econ. 2020, 229, 107776. [CrossRef]

23. Stock, T.; Seliger, G. Opportunities of Sustainable Manufacturing in Industry 4.0. Procedia CIRP 2016, 40, 536-541. [CrossRef]

24. Braccini, A.; Margherita, E. Exploring Organizational Sustainability of Industry 4.0 under the Triple Bottom Line: The Case of a Manufacturing Company. Sustainability 2018, 11,36. [CrossRef]

25. De Sousa Jabbour, A.B.L.; Jabbour, C.J.C.; Foropon, C.; Godinho Filho, M. When titans meet-Can industry 4.0 revolutionise the environmentally-sustainable manufacturing wave? The role of critical success factors. Technol. Forecast. Soc. Chang. 2018, 132, 18-25. [CrossRef]

26. Bonilla, S.; Silva, H.; Terra da Silva, M.; Franco Gonçalves, R.; Sacomano, J. Industry 4.0 and Sustainability Implications: A Scenario-Based Analysis of the Impacts and Challenges. Sustainability 2018, 10, 3740. [CrossRef]

27. Lardo, A.; Mancini, D.; Paoloni, N.; Russo, G. The perspective of capability providers in creating a sustainable I4.0 environment. Manag. Decis. 2020, 58, 1759-1777. [CrossRef]

28. Brozzi, R.; Forti, D.; Rauch, E.; Matt, D.T. The Advantages of Industry 4.0 Applications for Sustainability: Results from a Sample of Manufacturing Companies. Sustainability 2020, 12, 3647. [CrossRef]

29. Kiel, D.; Müller, J.M.; Arnold, C.; Voigt, K.-I. Sustainable Industrial Value Creation: Benefits and Challenges of Industry 4.0. Int. J. Innov. Manag. 2017, 21, 1740015. [CrossRef]

30. Prause, G.; Atari, S. On sustainable production networks for Industry 4.0. Entrep. Sustain. Issues 2017, 4, 421-431. [CrossRef] 
31. Lozano, R. Analysing the use of tools, initiatives, and approaches to promote sustainability in corporations. Corp. Soc. Responsib. Environ. Manag. 2020, 27, 982-998. [CrossRef]

32. Bajic, B.; Rikalovic, A.; Suzic, N.; Piuri, V. Industry 4.0 Implementation Challenges and Opportunities: A Managerial Perspective. IEEE Syst. J. 2020, 1, 1-14. [CrossRef]

33. Haseeb, M.; Hussain, H.I.; Ślusarczyk, B.; Jermsittiparsert, K. Industry 4.0: A Solution towards Technology Challenges of Sustainable Business Performance. Soc. Sci. 2019, 8, 154. [CrossRef]

34. Kimatu, J.N. Evolution of strategic interactions from the triple to quad helix innovation models for sustainable development in the era of globalization. J. Innov. Entrep. 2016, 5, 16. [CrossRef]

35. Leydesdorff, L.; Meyer, M. Triple Helix indicators of knowledge-based innovation systems: Introduction to the special issue. Res. Policy 2006, 35, 1441-1449. [CrossRef]

36. Ranga, M.; Etzkowitz, H. Triple Helix Systems: An Analytical Framework for Innovation Policy and Practice in the Knowledge Society. Ind. High. Educ. 2013, 27, 237-262. [CrossRef]

37. Kamble, S.S.; Gunasekaran, A.; Gawankar, S.A. Sustainable Industry 4.0 framework: A systematic literature review identifying the current trends and future perspectives. Process Saf. Environ. Prot. 2018, 117, 408-425. [CrossRef]

38. Müller, J.M.; Kiel, D.; Voigt, K.-I. What Drives the Implementation of Industry 4.0? The Role of Opportunities and Challenges in the Context of Sustainability. Sustainability 2018, 10, 247. [CrossRef]

39. Lin, K.; Shyu, J.; Ding, K. A Cross-Strait Comparison of Innovation Policy under Industry 4.0 and Sustainability Development Transition. Sustainability 2017, 9, 786. [CrossRef]

40. Birkel, H.; Müller, J.M. Potentials of industry 4.0 for supply chain management within the triple bottom line of sustainability-A systematic literature review. J. Clean. Prod. 2021, 289, 125612. [CrossRef]

41. Meng, Y.; Yang, Y.; Chung, H.; Lee, P.-H.; Shao, C. Enhancing Sustainability and Energy Efficiency in Smart Factories: A Review. Sustainability 2018, 10, 4779. [CrossRef]

42. Manavalan, E.; Jayakrishna, K. A review of Internet of Things (IoT) embedded sustainable supply chain for industry 4.0 requirements. Comput. Ind. Eng. 2019, 127, 925-953. [CrossRef]

43. Nunhes, T.V.; Oliveira, O.J. Analysis of Integrated Management Systems research: Identifying core themes and trends for future studies. Total Qual. Manag. Bus. Excell. 2018, 31, 1-23. [CrossRef]

44. Alvarenga, A.B.C.d.; Espuny, M.; Reis, J.S.d.; Silva, F.d.; Sampaio, N.A.d.; Nunhes, T.V.; Barbosa, L.C.F.M.; Santos, G.; de Oliveira, O.J. The Main Perspectives of The Quality of Life of Students In The Secondary Cycle: An Overview of The Opportunities, Challenges and Their Greatest Impact Elements. Int. J. Qual. Res. 2021, 15. [CrossRef]

45. Hsieh, H.-F.; Shannon, S.E. Three Approaches to Qualitative Content Analysis. Qual. Health Res. 2005, 15, 1277-1288. [CrossRef]

46. Swarnima, C.; Mehra, P.; Dasot, A. India's Readiness for Industry 4.0-A Focus on Automotive Sector. Available online: http:/ / www.grantthornton.in/insights/articles/indias-readiness-for-industry-4.0--a-focus-on-automotive-sector/ (accessed on 18 August 2020).

47. Prause, G. Sustainable Business Models and Structures for Industry 4.0. J. Secur. Sustain. Issues 2015, 5, 159-169. [CrossRef]

48. Branger, J.; Pang, Z. From automated home to sustainable, healthy and manufacturing home: A new story enabled by the Internet-of-Things and Industry 4.0. J. Manag. Anal. 2015, 2, 314-332. [CrossRef]

49. Hirsch, J.E. Does the h index have predictive power? Proc. Natl. Acad. Sci. USA 2007, 104, 19193-19198. [CrossRef]

50. Nunhes, T.V.; Garcia, E.V.; Espuny, M.; de Melo Santos, V.H.; Isaksson, R.; José de Oliveira, O. Where to Go with Corporate Sustainability? Opening Paths for Sustainable Businesses through the Collaboration between Universities, Governments, and Organizations. Sustainability 2021, 13, 1429. [CrossRef]

51. Scopus Scopus. Available online: https://www.scopus.com/home.uri (accessed on 8 July 2020).

52. Orbit Patent. Available online: https:/ / www32.orbit.com/ (accessed on 17 July 2020).

53. Schneider Electric about Us. Available online: https://www.se.com/in/en/about-us/company-profile/ (accessed on 20 August 2020).

54. Schneider Electric EcoStruxure ${ }^{\mathrm{TM}}$. Available online: https://www.se.com/in/en/work/campaign/innovation/overview.jsp (accessed on 20 August 2020).

55. Schneider Electric EcoStruxure ${ }^{\mathrm{TM}}$ Building. Available online: https://www.se.com/in/en/work/campaign/innovation/ buildings.jsp (accessed on 20 August 2020).

56. Ghadimi, P.; Wang, C.; Lim, M.K.; Heavey, C. Intelligent sustainable supplier selection using multi-agent technology: Theory and application for Industry 4.0 supply chains. Comput. Ind. Eng. 2019, 127, 588-600. [CrossRef]

57. VST Mobility Solutions about Us. Available online: https://vstmobility.com/about.php (accessed on 28 August 2020).

58. VST Mobility Solutions IoT Services. Available online: https://vstmobility.com/ser_iot.php (accessed on 28 August 2020).

59. VST Mobility Solutions BIN-19. Available online: https://vstmobility.com/bin-19.php (accessed on 28 August 2020).

60. Da Motta Reis, J.S.; Silva, F.d.; Espuny, M.; Alexandre, L.G.L.; Barbosa, L.C.F.M.; Bonassa, A.C.M.; Faria, A.M.; Sampaio, N.A.d.; Santos, G.; de Oliveira, O.J. The Rapid Escalation of Publications on Covid-19: A Snapshot of Trends in the Early Months to Overcome the Pandemic and to Improve Life Quality. Int. J. Qual. Res. 2020, 14, 951-968. [CrossRef]

61. Chung, M.; Bernheim, A.; Mei, X.; Zhang, N.; Huang, M.; Zeng, X.; Cui, J.; Xu, W.; Yang, Y.; Fayad, Z.A.; et al. CT Imaging Features of 2019 Novel Coronavirus (2019-nCoV). Radiology 2020, 295, 202-207. [CrossRef] [PubMed] 
62. National Institute of Industrial Engineering Vision e Mission. Available online: https://www.nitie.ac.in/vision-mission (accessed on 30 August 2020).

63. Yadav, G.; Kumar, A.; Luthra, S.; Garza-Reyes, J.A.; Kumar, V.; Batista, L. A framework to achieve sustainability in manufacturing organisations of developing economies using industry 4.0 technologies' enablers. Comput. Ind. 2020, 122, 103280. [CrossRef]

64. Yadav, G.; Luthra, S.; Jakhar, S.K.; Mangla, S.K.; Rai, D.P. A framework to overcome sustainable supply chain challenges through solution measures of industry 4.0 and circular economy: An automotive case. J. Clean. Prod. 2020, 254, 120112. [CrossRef]

65. Luthra, S.; Mangla, S.K. Evaluating challenges to Industry 4.0 initiatives for supply chain sustainability in emerging economies. Process Saf. Environ. Prot. 2018, 117, 168-179. [CrossRef]

66. Indian Institute of Technology Delhi Departments. Available online: https:/ / home.iitd.ac.in/departments.php (accessed on 3 September 2020).

67. United States Environmental Protection Agency. EPA Celebrates 50 Years of Research for a Healthier Environment. Available online: https:/ / www.epa.gov/newsreleases/epa-celebrates-50-years-research-healthier-environment (accessed on 9 August 2020).

68. Dernbach, J.C.; Mintz, J.A. Environmental Laws and Sustainability: An Introduction. Sustainability 2011, 3, 531-540. [CrossRef]

69. United States Environmental Protection Agency. Smart City Air Challenge Resource Pages: Community Case Studies. Available online: https: / / developer.epa.gov/ city-case-studies/ (accessed on 12 August 2020).

70. OECD Greenhouse Gas Emissions by Source. Available online: https://www.oecd-ilibrary.org/environment/data/oecdenvironment-statistics/greenhouse-gas-emissions_data-00594-en (accessed on 24 June 2020).

71. IBM About IBM. Available online: https://www.ibm.com/ibm/us/en/?lnk=fai-maib-usen (accessed on 10 August 2020).

72. IBM Energy and Environment. Available online: https://www.ibm.com/ibm/green/ (accessed on 10 August 2020).

73. Xerox about Xerox. Available online: https://www.xerox.com/en-us/about (accessed on 11 August 2020).

74. Xerox Xerox DocuShare Flex. Available online: https://www.xerox.com/pt-br/servicos-empresariais/solucoes-de-gestao-deconteudo-corporativo/docushare-flex (accessed on 18 August 2020).

75. Xerox Como a Xerox ${ }^{\circledR}$ DocuShare ${ }^{\circledR}$ Ajudou um Fabricante de Móveis de 99 anos a Digitalizar 500.000 Documentos. Available online: https:/ / www.xerox.com/pt-br/servicos-empresariais/solucoes-de-gestao-de-conteudo-corporativo/docushare-estudode-caso-sobre-eficiencia-do-fluxo-de-trabalho (accessed on 18 August 2020).

76. Newell, J.P.; Vos, R.O. "Papering" Over Space and Place: Product Carbon Footprint Modeling in the Global Paper Industry. Ann. Assoc. Am. Geogr. 2011, 101, 730-741. [CrossRef]

77. SunTracker Technologies Our Company. Available online: https://www.suntrackertech.com/about/ (accessed on 11 August 2020).

78. Moschetti, R.; Mazzarella, L.; Nord, N. An overall methodology to define reference values for building sustainability parameters. Energy Build. 2015, 88, 413-427. [CrossRef]

79. Banani, R.; Vahdati, M.M.; Shahrestani, M.; Clements-Croome, D. The development of building assessment criteria framework for sustainable non-residential buildings in Saudi Arabia. Sustain. Cities Soc. 2016, 26, 289-305. [CrossRef]

80. SunTracker Technologies Horticultural Lighting Design. Available online: https://www.suntrackertech.com/horticultural/ (accessed on 18 August 2020).

81. United Nations Goal 2: Zero Hunger. Available online: https://www.un.org/sustainabledevelopment/hunger/ (accessed on 16 June 2020).

82. California State University Bakersfield CSUB Sustainability. Available online: https://www.csub.edu/sustainability/ (accessed on 18 August 2020).

83. Reis, J.S.d.; Costa, A.C.F.; Espuny, M.; Batista, W.J.; Francisco, F.E.; Gonçalves, G.S.; Tasinaffo, P.M.; Dias, L.A.V.; da Cunha, A.M.; de Oliveira, O.J. Education 4.0: Gaps Research Between School Formation and Technological Development. In Proceedings of the 17th International Conference on Information Technology-New Generations (ITNG 2020); Latifi, S., Ed.; Springer: Cham, Switzerland, 2020; pp. 415-420. ISBN 978-3-030-43020-7.

84. Kamble, S.; Gunasekaran, A.; Dhone, N.C. Industry 4.0 and lean manufacturing practices for sustainable organisational performance in Indian manufacturing companies. Int. J. Prod. Res. 2019, 58, 1-19. [CrossRef]

85. Tuffnell, C.; Král, P.; Durana, P.; Krulicky, T. Industry 4.0-based Manufacturing Systems: Smart Production, Sustainable Supply Chain Networks, and Real-Time Process Monitoring. J. Self-Gov. Manag. Econ. 2019, 7, 7-12.

86. Ainsworth-Rowen, E. Networked, Smart, and Responsive Devices in Sustainable Internet-of-Things-based Manufacturing Systems: Industrial Value Creation, Cognitive Decision-Making Algorithms, and Operational Performance Improvement. Econ. Manag. Financ. Mark. 2019, 14, 9.

87. Tuffnell, C.; Král, P.; Siekelova, A.; Horák, J. Cyber-Physical Smart Manufacturing Systems: Sustainable Industrial Networks, Cognitive Automation, and Data-Centric Business Models. Econ. Manag. Financ. Mark. 2019, 14, 58.

88. Fielden, A.; Michalkova, L.; Vrbka, J.; Lyakina, M. Smart Sustainable Data-driven Manufacturing: Cyber-Physical Production Systems and Internet of Things Sensing Networks. J. Self-Gov. Manag. Econ. 2019, 7, 7-13.

89. Felstead, M. Cyber-Physical Production Systems in Industry 4.0: Smart Factory Performance, Innovation-driven Manufacturing Process Innovation, and Sustainable Supply Chain Networks. Econ. Manag. Financ. Mark. 2019, 14, 37.

90. American Association for Economic Research ISBDA. Available online: https://aa-er.org/isbda?fbclid=IwAR18WjYSm6 LqAMtXhvWDR_mlNLP9TjP5KraHAPmODcYhSWm5viZHqoB0tg8 (accessed on 19 August 2020). 
91. Esmaeilian, B.; Sarkis, J.; Lewis, K.; Behdad, S. Blockchain for the future of sustainable supply chain management in Industry 4.0. Resour. Conserv. Recycl. 2020, 163, 105064. [CrossRef]

92. International Monetary Fund. The People's Republic of China: 2016 Article IV Consultation-Press Release; Staff Report; and Statement by the Executive Director for The People's Republic of China. Available online: https:/ /www.imf.org/en/Publications/CR/ Issues /2016/12/31/The-People-s-Republic-of-China-2016-Article-IV-Consultation-Press-Release-Staff-Report-and-44181 (accessed on 7 September 2020).

93. Asian Development Bank People's Republic of China: Country Partnership Strategy (2016-2020). Available online: https: //www.adb.org/documents/peoples-republic-china-country-partnership-strategy-2016-2020 (accessed on 10 September 2020).

94. Müller, J.M.; Voigt, K.-I. Sustainable Industrial Value Creation in SMEs: A Comparison between Industry 4.0 and Made in China 2025. Int. J. Precis. Eng. Manuf. Technol. 2018, 5, 659-670. [CrossRef]

95. The People's Republic of China Made in China 2025. Available online: http://english.www.gov.cn/2016special/madeinchina202 5/ (accessed on 7 September 2020).

96. Institute for Security and Development Policy Made in China 2025. Available online: https://isdp.eu/publication/made-china2025/ (accessed on 8 September 2020).

97. Southeast University About SEU. Available online: https://www.seu.edu.cn/english/_t1875/22456/list.psp (accessed on 8 September 2020).

98. National Mobile Communications Research Laboratory Main Scientific Research Results. Available online: https://ncrl.seu.edu. cn/15596/list.htm (accessed on 9 August 2020).

99. Birkel, H.; Veile, J.; Müller, J.M.; Hartmann, E.; Voigt, K.-I. Development of a Risk Framework for Industry 4.0 in the Context of Sustainability for Established Manufacturers. Sustainability 2019, 11, 384. [CrossRef]

100. China Datang Company Profile. Available online: http://www.cccme.org.cn/shop/cccme8991/introduction.aspx (accessed on 10 September 2020).

101. Zhejiang Haikang Technology Company Profile. Available online: http://www.hiklife.com/Corporate/Company-Profile (accessed on 12 September 2020).

102. Zhejiang Haikang Technology Awake. Available online: http://www.hiklife.com/solution/Alert-series (accessed on 12 September 2020).

103. Dalian University of Technology about DUT. Available online: https://en.dlut.edu.cn/Research/Research_Overview.htm (accessed on 12 September 2020).

104. Beijing University of Technology about BJUT. Available online: http://english.bjut.edu.cn/About/About_BJUT.htm (accessed on 25 September 2020).

105. Chongqing University an Overview. Available online: http:// english.cqu.edu.cn/ (accessed on 25 September 2020).

106. Ren, S.; Zhang, Y.; Liu, Y.; Sakao, T.; Huisingh, D.; Almeida, C.M.V.B. A comprehensive review of big data analytics throughout product lifecycle to support sustainable smart manufacturing: A framework, challenges and future research directions. J. Clean. Prod. 2019, 210, 1343-1365. [CrossRef]

107. Bundestag, D. Bundesbericht Forschung und Innovation 2020. Available online: https://dip21.bundestag.de/dip21/btd/19/193 /1919310.pdf (accessed on 26 June 2020).

108. Bundestag, D. Integrierter Nationaler Energie- und Klimaplan. Available online: https://dip21.bundestag.de/dip21/btd/19/203 /1920364.pdf (accessed on 31 June 2020).

109. Hannover Messe about Us. Available online: https:/ / www.hannovermesse.de/en/about-us/about-the-show / (accessed on 1 July 2020).

110. Tao, F.; Wang, Y.; Zuo, Y.; Yang, H.; Zhang, M. Internet of Things in product life-cycle energy management. J. Ind. Inf. Integr. 2016, 1, 26-39. [CrossRef]

111. Odd.Bot agRobotics for a Sustainable Future. Available online: https://www.hannovermesse.de/exhibitor/odd-bot/N1449701 (accessed on 1 July 2020).

112. Elahi, E.; Weijun, C.; Zhang, H.; Nazeer, M. Agricultural intensification and damages to human health in relation to agrochemicals: Application of artificial intelligence. Land Use Policy 2019, 83, 461-474. [CrossRef]

113. Cybus Cybus Connectware Gateway and Integration Platform. Available online: https://www.messe.de/apollo/hannover_ messe_2020/obs/Binary/A1020767/Cybus_Connectware_OnePager_FO_2019.pdf (accessed on 1 July 2020).

114. Friedrich-Alexander-Universität Erlangen-Nürnberg Seven Unique Research Areas. Available online: https://www.wiso.rw.fau. $\mathrm{eu} /$ research/research-profile/research-focus-areas/ (accessed on 25 June 2020).

115. Bauhütte 4.0 Bauhütte 4.0. Available online: https:/ / www.bauhuette40.com/ (accessed on 25 June 2020).

116. Abgeordnetenhaus von Berlin Nachhaltigkeit auf dem Bau: Berlin baut mit Holz. Available online: https://www.parlamentberlin.de/ados/18/IIIPlen/vorgang/d18-2225.pdf (accessed on 1 August 2020).

117. Kisku, N.; Joshi, H.; Ansari, M.; Panda, S.K.; Nayak, S.; Dutta, S.C. A critical review and assessment for usage of recycled aggregate as sustainable construction material. Constr. Build. Mater. 2017, 131, 721-740. [CrossRef]

118. Bag, S.; Telukdarie, A.; Pretorius, J.H.C.; Gupta, S. Industry 4.0 and supply chain sustainability: Framework and future research directions. Benchmarking Int. J. 2018. [CrossRef]

119. Yazdi, P.G.; Azizi, A.; Hashemipour, M. An Empirical Investigation of the Relationship between Overall Equipment Efficiency (OEE) and Manufacturing Sustainability in Industry 4.0 with Time Study Approach. Sustainability 2018, 10, 3031. [CrossRef] 
120. Kumar, R.; Singh, S.P.; Lamba, K. Sustainable robust layout using Big Data approach: A key towards industry 4.0. J. Clean. Prod. 2018, 204, 643-659. [CrossRef]

121. Shim, S.-O.; Park, K.; Choi, S. Sustainable Production Scheduling in Open Innovation Perspective under the Fourth Industrial Revolution. J. Open Innov. Technol. Mark. Complex. 2018, 4, 42. [CrossRef]

122. Ding, B. Pharma Industry 4.0: Literature review and research opportunities in sustainable pharmaceutical supply chains. Process Saf. Environ. Prot. 2018, 119, 115-130. [CrossRef]

123. Franciosi, C.; Iung, B.; Miranda, S.; Riemma, S. Maintenance for Sustainability in the Industry 4.0 context: A Scoping Literature Review. IFAC PapersOnLine 2018, 51, 903-908. [CrossRef]

124. Garrido-Hidalgo, C.; Hortelano, D.; Roda-Sanchez, L.; Olivares, T.; Ruiz, M.C.; Lopez, V. IoT Heterogeneous Mesh Network Deployment for Human-in-the-Loop Challenges Towards a Social and Sustainable Industry 4.0. IEEE Access 2018, 6, 28417-28437. [CrossRef]

125. Ardanza, A.; Moreno, A.; Segura, Á.; de la Cruz, M.; Aguinaga, D. Sustainable and flexible industrial human machine interfaces to support adaptable applications in the Industry 4.0 paradigm. Int. J. Prod. Res. 2019, 57, 4045-4059. [CrossRef]

126. De Sousa Jabbour, A.B.L.; Jabbour, C.J.C.; Godinho Filho, M.; Roubaud, D. Industry 4.0 and the circular economy: A proposed research agenda and original roadmap for sustainable operations. Ann. Oper. Res. 2018, 270, 273-286.

127. Bányai, T.; Tamás, P.; Illés, B.; Stankevičiūtè, Ž.; Bányai, Á. Optimization of Municipal Waste Collection Routing: Impact of Industry 4.0 Technologies on Environmental Awareness and Sustainability. Int. J. Environ. Res. Public Health 2019, $16,634$. [CrossRef]

128. Batkovskiy, A.M.; Leonov, A.V.; Pronin, A.Y.; Semenova, E.G.; Fomina, A.V.; Balashov, V.M. Sustainable development of Industry 4.0: The case of high-tech products system design. Entrep. Sustain. Issues 2019, 6, 1823-1838. [CrossRef]

129. Stock, T.; Obenaus, M.; Kunz, S.; Kohl, H. Industry 4.0 as enabler for a sustainable development: A qualitative assessment of its ecological and social potential. Process Saf. Environ. Prot. 2018, 118, 254-267. [CrossRef]

130. Fatimah, Y.A.; Govindan, K.; Murniningsih, R.; Setiawan, A. Industry 4.0 based sustainable circular economy approach for smart waste management system to achieve sustainable development goals: A case study of Indonesia. J. Clean. Prod. 2020, $269,122263$. [CrossRef]

131. Oláh, J.; Aburumman, N.; Popp, J.; Khan, M.A.; Haddad, H.; Kitukutha, N. Impact of Industry 4.0 on Environmental Sustainability. Sustainability 2020, 12, 4674. [CrossRef]

132. Tiwari, K.; Khan, M.S. Sustainability accounting and reporting in the industry 4.0. J. Clean. Prod. 2020, 258, 120783. [CrossRef]

133. Bag, S.; Gupta, S.; Kumar, S. Industry 4.0 adoption and 10R advance manufacturing capabilities for sustainable development. Int J. Prod. Econ. 2021, 231, 107844. [CrossRef]

134. Bai, X.; Ren, X.; Khanna, N.Z.; Zhou, N.; Hu, M. Comprehensive water footprint assessment of the dairy industry chain based on ISO 14046: A case study in China. Resour. Conserv. Recycl. 2018, 132, 369-375. [CrossRef]

135. Luthra, S.; Kumar, A.; Zavadskas, E.K.; Mangla, S.K.; Garza-Reyes, J.A. Industry 4.0 as an enabler of sustainability diffusion in supply chain: An analysis of influential strength of drivers in an emerging economy. Int. J. Prod. Res. 2020, 58, 1505-1521. [CrossRef]

136. Leng, J.; Ruan, G.; Jiang, P.; Xu, K.; Liu, Q.; Zhou, X.; Liu, C. Blockchain-empowered sustainable manufacturing and product lifecycle management in industry 4.0: A survey. Renew. Sustain. Energy Rev. 2020, 132, 110112. [CrossRef]

137. Kumar, P.; Singh, R.K.; Kumar, V. Managing supply chains for sustainable operations in the era of industry 4.0 and circular economy: Analysis of barriers. Resour. Conserv. Recycl. 2021, 164, 105215. [CrossRef]

138. Belhadi, A.; Kamble, S.S.; Zkik, K.; Cherrafi, A.; Touriki, F.E. The integrated effect of Big Data Analytics, Lean Six Sigma and Green Manufacturing on the environmental performance of manufacturing companies: The case of North Africa. J. Clean. Prod. 2020, 252, 119903. [CrossRef]

139. Sharma, M.; Kamble, S.; Mani, V.; Sehrawat, R.; Belhadi, A.; Sharma, V. Industry 4.0 adoption for sustainability in multi-tier manufacturing supply chain in emerging economies. J. Clean. Prod. 2021, 281, 125013. [CrossRef]

140. Gupta, H.; Kumar, A.; Wasan, P. Industry 4.0, cleaner production and circular economy: An integrative framework for evaluating ethical and sustainable business performance of manufacturing organizations. J. Clean. Prod. 2021, 295, 126253. [CrossRef] 